\title{
Crustal-scale cross-sections across the NW Zagros belt: implications for the Arabian margin reconstruction
}

\author{
J. VERGÉS*, E. SAURA, E. CASCIELLO, M. FERNÀNDEZ, A. VILLASEÑOR, \\ I. JIMÉNEZ-MUNT \& D. GARCÍA-CASTELLANOS
}

Group of Dynamics of the Lithosphere (GDL), Institute of Earth Sciences 'Jaume Almera', CSIC, 08028 Barcelona, Spain

(Received 30 October 2010; accepted 1 February 2011)

\begin{abstract}
Quantified balanced and restored crustal cross-sections across the NW Zagros Mountains are presented in this work integrating geological and geophysical local and global datasets. The balanced crustal cross-section reproduces the surficial folding and thrusting of the thick cover succession, including the near top of the Sarvak Formation $(\sim 90 \mathrm{Ma})$ that forms the top of the restored crustal cross-section. The base of the Arabian crust in the balanced cross-section is constrained by recently published seismic receiver function results showing a deepening of the Moho from $42 \pm 2 \mathrm{~km}$ in the undeformed foreland basin to $56 \pm 2 \mathrm{~km}$ beneath the High Zagros. The internal parts of the deformed crustal cross-section are constrained by new seismic tomographic sections imaging a $\sim 50^{\circ}$ NE-dipping sharp contact between the Arabian and Iranian crusts. These surfaces bound an area of $10800 \mathrm{~km}^{2}$ that should be kept constant during the Zagros orogeny. The Arabian crustal cross-section is restored using six different tectonosedimentary domains according to their sedimentary facies and palaeobathymetries, and assuming Airy isostasy and area conservation. While the two southwestern domains were directly determined from well-constrained surface data, the reconstruction of the distal domains to the NE was made using the recent margin model of Wrobel-Daveau et al. (2010) and fitting the total area calculated in the balanced cross-section. The Arabian continental-oceanic boundary, at the time corresponding to the near top of the Sarvak Formation, is located $169 \mathrm{~km}$ to the NE of the trace of the Main Recent Fault. Shortening is estimated at $\sim 180 \mathrm{~km}$ for the cover rocks and $\sim 149 \mathrm{~km}$ for the Arabian basement, including all compressional events from Late Cretaceous to Recent time, with an average shortening rate of $\sim 2 \mathrm{~mm} \mathrm{yr}^{-1}$ for the last $90 \mathrm{Ma}$.
\end{abstract}

Keywords: Zagros orogen, Arabian margin, shortening, thrusting, folding.

\section{Introduction}

The Zagros mountain range formed between the converging Arabian and Eurasian plates during the closure of the Neo-Tethys Ocean (Stöcklin, 1968; Talbot \& Alavi, 1996; Stampfli \& Borel, 2002). This process involved three main units: the Arabian passive margin to the SW, the southwestern margin of the Eurasian plate to the NE, and the Central Iranian microplates located in between Arabia and Eurasia (Golonka, 2004). The Arabian passive margin originated from the opening of the Neo-Tethys Ocean during Permian-Early Triassic rifting and experienced stable and subsiding conditions during most of the Mesozoic (Stampfli \& Borel, 2002). During Late Jurassic-Early Cretaceous time the Neo-Tethys Ocean started subducting under the Eurasian plate and a convergence setting began (Golonka, 2004). From Late Cretaceous to Pliocene time, three major stages of development are known in the Zagros region. Initial obduction of oceanic crust above the Arabian continental margin was followed by collision with island arcs and finally by the continental collision between the

\footnotetext{
*Author for correspondence: jverges@ija.csic.es
}

Arabian block and the Central Iranian block resulting in a calculated amount of convergence of $\sim 1300 \mathrm{~km}$ since $56 \mathrm{Ma}$ (McQuarrie et al. 2003) of which $\sim 500$ $800 \mathrm{~km}$ occurred only since 35-23 Ma (Hatzfeld \& Molnar, 2010). This multistage convergence between the Arabian and Iranian blocks resulted in a protracted, however, discontinuous compression of the NE Arabian margin (e.g. Homke et al. 2010). According to geodetic measurements the northwards motion of the Arabian plate, with respect to a fixed Eurasian plate, is still active today with velocities ranging between 1.6 and $2.2 \mathrm{~cm} \mathrm{yr}^{-1}$ (Fig. 1; Sella, Dixon \& Mao, 2002; Vernant et al. 2004).

Recent studies in the external Zagros have shown that the earliest deformation events related to the obduction of Neo-Tethyan oceanic crust were not only recorded in the hinterland of the chain but also in several anticlines of the external portions of the Zagros Fold Belt (Homke et al. 2009; Piryaei et al. 2010; Saura et al. 2011). In addition, the onset of the main deformation event (continental collision) was found to be older than previously thought (e.g. Fakhari et al. 2008; Homke et al. 2010; Gavillot et al. 2010). These new results are consistent with the protracted nature of the formation of the Zagros mountain belt and provide 


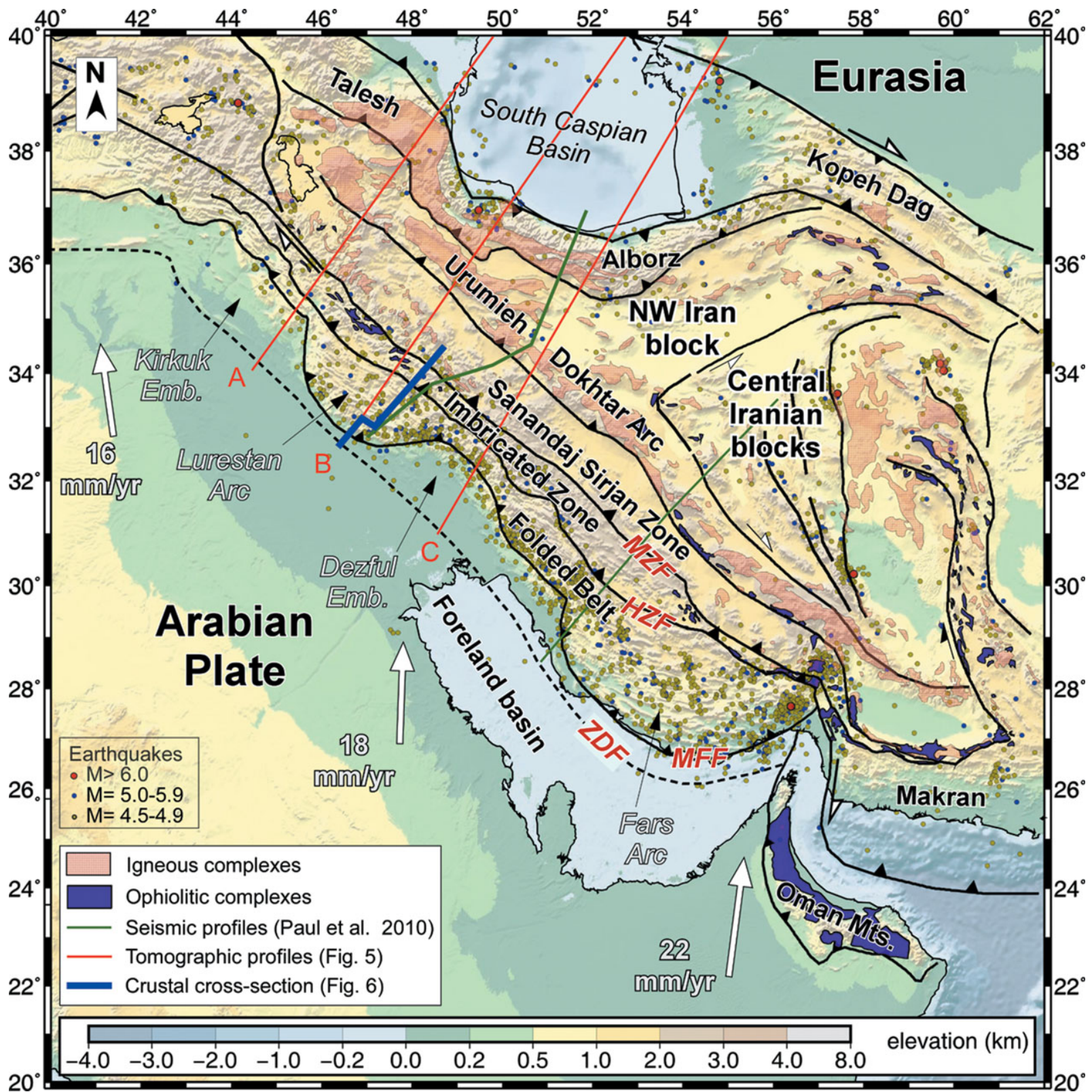

Figure 1. (Colour online) Topographic map of Iran showing the main tectonic units, including major igneous and ophiolitic complexes, the location of balanced cross-section, seismic profiles by Paul et al. (2010) and new regional seismic tomographic profiles. Relative plate velocities refer to the northwards motion of the Arabian plate with respect to a fixed Eurasian plate (Sella, Dixon \& Mao, 2002; Vernant et al. 2004). ZDF - Zagros Deformation Front; MFF - Mountain Front Flexure; HZF - High Zagros Fault; MZF - Main Zagros Fault. Earthquake locations and magnitude are from 1973 to present USGS database. The Pusht-e Kuh arc is also known as Lurestan arc.

new constraints on the timing and evolution of this hydrocarbon-rich province. Despite this long history of convergence and the extrapolated velocity vectors, the available shortening calculations across the Zagros mountain belt are surprisingly low, which contradicts what is expected from large-scale reconstructions (e.g. Barrier \& Vrielynck, 2008). A few tens of kilometres of shortening are generally observed in the folded region of the Zagros Fold Belt (e.g. Blanc et al. 2003; Sherkati \& Letouzey, 2004; Molinaro et al. 2005), whereas in the remaining inner portions of the belt, amounts of shortening are largely unknown or poorly constrained.
The aim of this paper is to present coupled areabalanced and restored cross-sections across the NW Zagros based on available geological and geophysical data to fully constrain both the present-day crustal geometry of the Zagros belt and the Arabian margin geometry during Late Cretaceous time before the onset of compression. The balanced cross-section includes available surficial and deep data to delimit the presentday crustal area and constrain the reconstruction of the Arabian margin. The restored crustal cross-section represents the first attempt to quantitatively reconstruct the Arabian margin during Late Cretaceous time before oceanic obduction and subsequent continental 
collision. This reconstruction employs both line-length balancing techniques for the Upper Cretaceous sedimentary cover (near top of the Sarvak Formation) and area balancing techniques constrained by the minimum lengths of the restored tectonosedimentary domains that compose the balanced cross-section and their estimated palaeobathymetries, assuming Airy isostasy. The comparison between balanced and restored sections opens the possibility to discuss potential shortening amounts across the Arabian margin and their rates through time, to constrain the structure of the cover and basement thrust systems and the sequence of deformation in the Zagros Fold Belt.

\section{1.a. Tectonic domains of the Zagros orogenic belt}

The NW-SE-trending Zagros mountain belt is formed by five different parallel structural domains, from SW to NE: (1) the Mesopotamian-Persian Gulf foreland basin, (2) the Simply Folded Belt, (3) the Imbricate Zone (also called High Zagros Thrust Belt or Crush Zone), (4) the metamorphic and magmatic SanandajSirjan Zone, and (5) the Urumieh-Dokhtar Magmatic Arc (Fig. 1). These structural domains are separated by major faults, which have been the subject of study by different authors.

The Zagros Simply Folded Belt and the Mesopotamian foreland basin are the externalmost domains of the Zagros orogen. The boundary between these two domains is the Mountain Front Flexure (MFF; also known as Mountain Front Fault), a major morphotectonic discontinuity that uplifts the Simply Folded Belt by a few kilometres with respect to the foreland (Falcon, 1961; Berberian, 1995; Sepehr \& Cosgrove, 2004; Emami et al. 2010). The Mountain Front Flexure is marked by intense seismic activity occurring at depths between 10 and $20 \mathrm{~km}$ (Engdahl et al. 2006), and displays a sinuous trace that defines two salients (Lurestan or Pusht-e Kuh arc and Fars arc) and two reentrants (Kirkuk Embayment and Dezful Embayment) (Fig. 1). Deformation in the Zagros Fold Belt is thought to occur mainly through detachment folding of lithologically competent units above weak detachments of regional extent (e.g. Colman-Sadd, 1978; Sepehr \& Cosgrove, 2004; Rudkiewicz, Sherkati \& Letouzey, 2007; Casciello et al. 2009). Magnetostratigraphic dating of syntectonic deposits indicates that folding reached the frontal part of the Pusht-e Kuh arc around $7.6 \pm 0.5 \mathrm{Ma}$ and was active until the PliocenePleistocene boundary at about $2.5 \mathrm{Ma}$ (Homke et al. 2004). Growth strata in the basal deposits of the Bakhtyari conglomerates indicate that folding occurred as early as $14-15 \mathrm{Ma}$ (Mid-Miocene) in more internal areas of the Simply Folded Belt near the NE side of the Fars arc (Khadivi et al. 2010).

The Imbricate Zone is a highly deformed domain, involving multiple tectonic thrust sheets, which are separated from the Simply Folded Belt by the High Zagros Fault (HZF, Berberian, 1995) (Figs 1, 2). The thick pile of thrust sheets composing the Imbricate
Zone includes, from bottom to top: (1) the distal part of the Arabian margin (Braud, 1970; Nemati \& Yassaghi, 2010), which we label the Outer Lurestan margin; (2) the Kermanshah Complex, composed of the Radiolarite basin, the Harsin basin and the Bisotun limestone; and (3) the Gaveh Rud domain (Fig. 2). The stacking of the Imbricate Zone occurred in several tectonic pulses from Santonian to Miocene times (Berthier et al. 1974; Gidon et al. 1974; Braud, 1987; Gavillot et al. 2010) as recorded by abundant syntectonic deposits (Braud, 1987; Agard et al. 2005, Fakhari et al. 2008). Each one of the units is separated by thrusting but there is no consensus about their extent and interpretation (Fig. 2). In this paper we use the term Kermanshah thrust to define the basal thrust of the Kermanshah Complex. In addition, the Gaveh Rud domain included in the Kermanshah Complex is not considered part of the Arabian margin in this study since they were separated by the Neo-Tethys oceanic domain.

The Sanandaj-Sirjan Zone is a $\sim 150-200 \mathrm{~km}$ wide tectonic domain, thrusted on top of the Gaveh Rud domain above the Main Zagros Fault (MZF) (e.g. Falcon, 1967; Stöklin, 1968). The Sanandaj-Sirjan Zone shows S- to SW-directed, NW-SE-trending folds and thrusts involving sedimentary and metamorphic rocks of Palaeozoic to Cretaceous age (Alavi, 1994; F. Masoudi, unpub. Ph.D. thesis, Univ. Leeds, 1997) (Figs 1, 2). Within this domain, Jurassic to Early Eocene calc-alkaline magmatism was followed by Mid Eocene gabbroic plutonism (e.g. Valizadeh \& Cantagrel, 1975; Berberian \& Berberian, 1981; F. Masoudi, unpub. Ph.D. thesis, Univ. Leeds, 1997; Baharifar et al. 2004, Leterrier, 1985; Braud, 1987). The Main Zagros Fault is a high-angle fault zone showing large segments with reverse kinematics (Main Zagros Reverse Fault; Stöcklin, 1968; Berberian, 1995) and younger portions with right-lateral offsets (Main Recent Fault; Talebian \& Jackson, 2002). In the study region, however, the frontal segment of the Main Zagros Fault is low angle, carrying Sanandaj-Sirjan rocks on top of the Radiolarite basin.

The Tertiary Urumieh-Dokhtar Magmatic Arc corresponds to a $50-100 \mathrm{~km}$ wide tectonic domain located to the NE of the Sanandaj-Sirjan Zone (Fig. 1). This domain is generally regarded as an Andeantype magmatic arc formed on the Iranian continental crust in response to the northwards subduction of the Neo-Tethys Ocean (e.g. Berberian et al. 1982). Calc-alkaline magmatic activity started in the central part of the arc during Eocene time, and climaxed during Oligocene-Miocene time (Berberian et al. 1982; Bernard et al. 1979; Martel-Jentin et al. 1979; Bina et al. 1986). According to Berberian \& Berberian (1981), calc-alkaline magmatism ended around $5 \mathrm{Ma}$ (Late Miocene) and was replaced by alkaline volcanism in Central Iran and SE Turkey, which is interpreted as resulting from slab break-off processes by Ghasemi \& Talbot (2006). The youngest lavas of the UrumiehDokhtar Magmatic Arc are Quaternary in age (Alavi, 1994). 


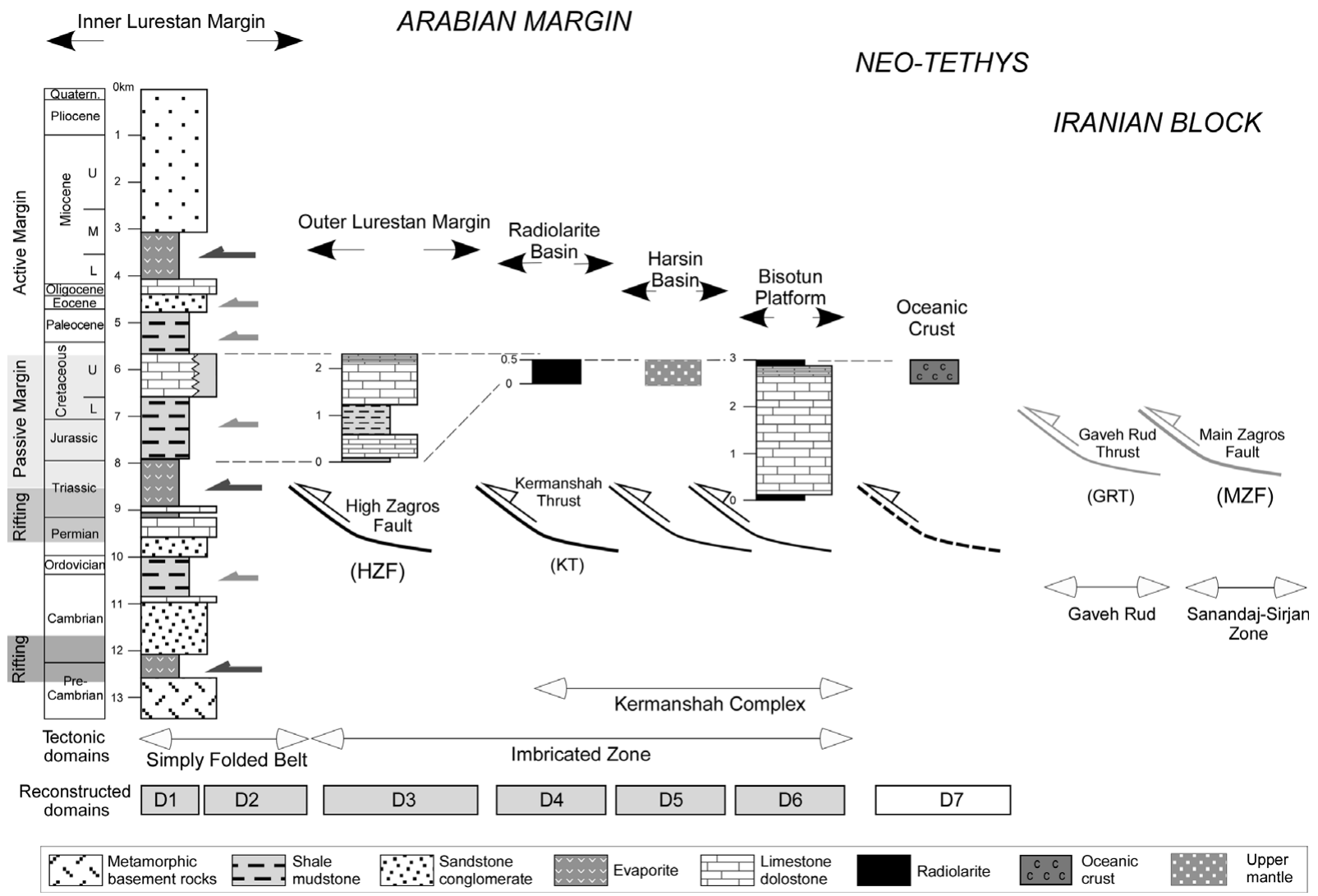

Figure 2. Simplified stratigraphic panel of the Arabian margin from SW to NE focusing on the Mesozoic passive margin period. Present-day tectonic domains, principal palaeogeographic depositional units, main thrusts and domains used for the presented crustalscale restoration are indicated. The Gaveh Rud and the Sanandaj-Sirjan Zone are not included in our reconstruction of the Arabian margin during Late Cretaceous time. The lengths of the reconstructed domains (D1 to D6) are not to scale in this figure.

\section{Zagros stratigraphy along the balanced cross-section}

The stratigraphy of the Zagros mountain belt has been extensively studied over the last century, favoured by exceptional conditions of exposure and propelled by the large hydrocarbon potential of the Simply Folded Belt and Dezful Embayment. In this Section, we present a short review of the stratigraphy along the balanced cross-section with special emphasis on the Upper Cretaceous interval (near top of the Sarvak Formation at about $90 \mathrm{Ma}$ ), which corresponds to the time at which we reconstruct the Arabian margin, prior to the onset of prolonged compression stages (Fig. 2). The complete sedimentary cover of the Zagros is estimated to measure $10-14 \mathrm{~km}$ in thickness and is the result of various tectonosedimentary events spanning from Late Proterozoic to Cenozoic time. The Late ProterozoicEarly Cambrian rifting phase resulted in deposition of evaporites corresponding to the Hormuz Formation, which is documented by over 200 salt plugs in the Fars province and in the SE segment of the Izeh Zone (Berberian \& King, 1981; Sharland, et al. 2001; Callot, Jahani \& Letouzey, 2007; Jahani et al. 2007). Large faults with N, NE and NW orientations, characteristic of the Arabian plate (Alavi, 2007), are supposed to control the distribution and thickness of these older deposits beneath the Zagros Fold Belt (e.g. Egdell,
1996; Ziegler, 2001). Many authors extend these old basement N-S-trending fractures beneath the Zagros Fold Belt (e.g. Bahroudi \& Talbot, 2003; Ahmadhadi, Lacombe \& Daniel, 2007; Farzipour-Saein et al. 2009) although little is proven about their implication in the Tertiary development of the Simply Folded Belt.

During Cambrian-Early Permian time, the Zagros area corresponded to a vast and stable platform characterized by deposition of epicontinental deposits (mainly clastic sandstones and shales with minor carbonates and evaporites) and large sedimentary gaps. These gaps are interpreted either as the distant effect of the Hercynian orogeny (e.g. Szabo \& Kheradpir, 1978; Bordenave, 2008) or as the effect of thermal uplift along an incipient rift (Koop \& Stoneley, 1982).

Through Late Permian-Early Triassic time a new rifting phase stretched the lithosphere in a SW-NE direction, marking the initial opening of the Neo-Tethys Ocean (e.g. Stöcklin, 1968; Berberian \& King, 1981; Husseini, 1988) and thus creating the NE margin of the Arabian plate along a fairly regular NW-SE direction (Stampfli \& Borel, 2002; Barrier \& Vrielynck, 2008).

Stable passive margin conditions characterize this NE margin of the Arabian plate throughout the Mesozoic. The passive margin succession is widely exposed along the Simply Folded Belt (e.g. James \& Wynd, 1965) showing a different evolution in the 
Fars and Lurestan provinces. While the Fars province recorded neritic conditions throughout Jurassic and Early Cretaceous time, the Lurestan province remained a restricted area in which shales, pelagic limestones and evaporites were alternatively deposited (James \& Wynd, 1965; Setudehnia, 1978; Koop \& Stoneley, 1982, Casciello et al. 2009; Farzipour-Saein et al. 2009).

Towards the end of Cretaceous time the Neo-Tethys started closing and oceanic crust was obducted onto the Arabian margin causing the passive margin conditions to cease and the active Zagros foreland stage to set in. This occurred through the emplacement and piling up of large thrust sheets along the Arabian margin (Kermanshah Complex; Fig. 2) and the formation of a flexural basin filled with foreland clastic wedges (Amiran basin; e.g. James \& Wynd, 1965; Homke et al. 2009; Saura et al. 2011).

The compressional evolution of the Zagros is not continuous, showing two large clastic wedges forming in Late Cretaceous-Early Eocene time (Amiran basin, Homke et al. 2009; Saura et al. 2011) and in MiocenePliocene time (Gachsaran-Agha Jari and Bakhtyari basin), separated by periods of non-deposition or shallow-marine carbonates (Shahbazan and Asmari formations).

Recent field-based studies on the Kermanshah Complex by Wrobel-Daveau et al. (2010) propose a new palaeogeographic interpretation in which a highly extended basin exposing serpentinized peridotites (Harsin basin) separated the Radiolarite basin from the Bisotun continental block (Fig. 2). These serpentinized peridotites are interpreted as upper mantle rocks, and are presently exposed around the Kermanshah Complex. The Harsin basin formed during Early Jurassic time but was reactivated in Late Cretaceous time, before the Cenomanian (Wrobel-Daveau et al. 2010). This reconstruction of the Harsin basin located between the Radiolarite basin and the Bisotun continental block differs from previous models in which these serpentinized rocks were interpreted as ophiolites forming part of the Neo-Tethys oceanic domain to the NE of the Bisotun continental block (e.g. Braud, 1987; Agard et al. 2005).

In the balanced cross-section we assume a constant pre-Triassic stratigraphic succession and variable passive margin stratigraphy for each palaeogeographic domain into which the Arabian margin was subdivided in this study (Fig. 2). For more detailed stratigraphic information the interested reader should refer to the pioneering works by James \& Wynd (1965) and Braud (1970), and more recent contributions by different authors (e.g. Motiei, 1994, 1995; Alavi, 2004; Bordenave \& Hegre, 2005; Carruba et al. 2006; Heydari, 2008; Farzipour-Saein et al. 2009; Saura et al. 2011).

In order to schematize the structure of the Arabian passive margin during Late Cretaceous time, and for the purposes of modelling, the Lurestan region is divided from $\mathrm{SW}$ to NE into six palaeogeographic domains: domains 1 and 2 (Inner Lurestan margin), domain 3 (Outer Lurestan margin), domain 4 (Radiolarite basin), domain 5 (Harsin basin) and domain 6 (Bisotun block). The Neo-Tethys oceanic crust of domain 7 forms the NE limit of the Arabian margin and is not accounted for in calculations (Fig. 2).

During Late Cretaceous time, the Inner Lurestan margin (domains 1 and 2) was a restricted area in which both neritic and pelagic limestones were deposited, together with shales and minor evaporites (James \& Wynd, 1965; Setudehnia, 1978; Koop \& Stoneley, 1982) (Fig. 2). Available reconstructions of this area during Turonian time $(\sim 90 \mathrm{Ma})$ show that approximately $70 \%$ of this region experienced neritic conditions (domain 1) and the remaining $30 \%$ was under pelagic conditions (domain 2) (Setudehnia, 1978; Koop \& Stoneley, 1982).

The Outer Lurestan margin is composed of a thick Jurassic-Upper Cretaceous carbonate succession similar to the one found in the Inner Lurestan margin (e.g. Braud, 1970, Nemati \& Yassaghi, 2010), which was deposited in a pelagic environment during Late Cretaceous time (Braud, 1970) (Fig. 2). The Radiolarite basin is composed of $\sim 500 \mathrm{~m}$ of Triassic to Cretaceous radiolaritic successions (Braud, 1970), which indicate a persistent deep-water depositional setting for this unit during the Mesozoic. This Radiolarite basin corresponds to the deeper part of the Outer Lurestan margin, in contact with serpentinized upper mantle rocks of the Harsin basin. The Harsin basin, floored by serpentinized peridotites, is interpreted as a highly extended region during Late Cretaceous time exposing upper mantle rocks (Wrobel-Daveau et al. 2010) (Fig. 2). In the northeastern part of this domain, the Bisotun unit is formed by almost $3000 \mathrm{~m}$ of a Triassic to Upper Cretaceous carbonate succession (Fig. 2). In the upper part of this unit thin-bedded limestones with interbedded radiolarite beds document a pelagic depositional setting during Late Cretaceous time (Braud, 1970; Ricou, Braud \& Brunn, 1977). In our reconstruction, the northeastern margin of the Bisotun continental block may be assimilated to the boundary of the Arabian continental margin (Fig. 2).

As a summary of our reconstruction model, we propose a configuration of the Arabian margin defined by six domains with different palaeobathymetries at $\sim 90 \mathrm{Ma}$ (Fig. 2): domain 1, mostly covered by neritic limestones with an average palaeobathymetry of $50 \mathrm{~m}$; domain 2 , characterized by pelagic limestones with an average palaeobathymetry of $250 \mathrm{~m}$; domain 3, formed by pelagic limestones with an average palaeobathymetry of $500 \mathrm{~m}$; domain 4 , corresponding to the Radiolarite basin, with a proposed palaeobathymetry of $2100 \mathrm{~m}$; domain 5, composed of upper mantle rocks forming the Harsin basin (not accounted for in the area calculation since this domain is entirely composed of mantle rocks); and domain 6 corresponding to the Bisotun block, mostly characterized by carbonates grading into radiolarites with an estimated palaeobathymetry of 
$1000 \mathrm{~m}$. This domain is in contact with the Neo-Tethys oceanic domain 7 formed by young oceanic crust with a calculated water depth of $3250 \mathrm{~m}$.

\section{Zagros crustal geometry from previous works}

In this Section we describe relevant available data for the construction of the balanced and restored crustal cross-sections: (1) deformation style of the cover rocks and their link with the basement; (2) shortening amounts from regional cross-sections; (3) estimates of crustal thickness based on geophysical data; and (4) lithospheric structure.

\section{3.a. Deformation style of the cover rocks}

Despite the difficulty in drawing an unequivocal section at depth because of the lack of deep structural data, most papers seem to converge on a multidetachment system of folding to explain the deformation of the cover rocks (e.g. Blanc et al. 2003; McQuarrie, 2004; Molinaro et al. 2005; Carruba et al. 2006; Sepehr, Cosgrove \& Moieni, 2006; Sherkati, Letouzey \& Frizon de Lamotte, 2006; Mouthereau et al. 2007) (Fig. 3). A deeper discussion on the style of deformation for the cover rocks can be found in Vergés et al. (2011).

Interestingly, few of these works propose a satisfactory interpretation for the basement structures, accounting for both the shortening recorded by the cover and the uplift of the Fars and the Pusht-e Kuh arcs. Some authors propose imbrication of the basement below the detached cover (Sherkati, Letouzey \& Frizon de Lamotte, 2006; Mouthereau, Lacombe \& Meyer, 2006; Mouthereau et al. 2007; Molinaro et al. 2005; Carruba et al. 2006), while others suggest that large thrust faults with significant displacement cut through basement and cover (Blanc et al. 2003; Alavi, 2007). McQuarrie (2004) presented a discussion on the involvement of the basement in the deformation and concluded that most probably the cover is detached from the basement in the Lurestan and the Fars, with the basement only involved in the internal parts of the fold-thrust belt. The involvement of basement in the Zagros deformation is largely proved by seismicity occurring along reverse faults (e.g. Maggi et al. 2000; Talebian \& Jackson, 2004; Tatar, Hatzfeld \& GhaforiAshtiany, 2004; Hatzfeld et al. 2010) (Fig. 1). Although the geometry of these thrust systems is little known, it is proposed that they merge at depth with ductile shear zones in the middle-lower crust (Hatzfeld \& Molnar, 2010).

\section{3.b. Shortening based on geological cross-sections}

Several authors determined shortening values ranging from 45 to a maximum of $78 \mathrm{~km}$ across the Zagros Fold Belt using surficial data (e.g. Blanc et al. 2003; McQuarrie, 2004; Sherkati \& Letouzey, 2004; Molinaro et al. 2005; Mouthereau et al. 2007; Alavi, 2007) (see the location of cross-sections in Fig. 3).
However, these shortening values depend on the number of accounted tectonic units and on the style of assumed folding and thrusting, and therefore comparison is not straightforward.

Focusing on the Lurestan region we obtained shortening values of the sedimentary cover based on previously published cross-sections but across the same structural units (Fig. 3). Line length calculation of the near top of the Sarvak Formation from the foreland pin line to the footwall of the High Zagros Fault in the cross-section by Blanc et al. (2003) gives about $31 \mathrm{~km}$ of shortening (17.5\%). A similar calculation, from foreland to the footwall of the High Zagros Fault, using cross-section C by McQuarrie (2004) provides a total of $24 \mathrm{~km}$ of shortening (12.5\%). Shortening across the Simply Folded Belt, using cross-section B$\mathrm{B}^{\prime}$ by Alavi (2007), presents a slightly higher value of $36 \mathrm{~km}(17 \%)$ related to the $5 \mathrm{~km}$ and $6 \mathrm{~km}$ long ramps beneath the Maleh Kuh and the Sultan anticlines.

Detailed work carried out in the Lurestan region for individual anticlines shows $13.5 \%$ shortening in the Kabir Kuh anticline (Vergés et al. 2011) and $11.5 \%$ shortening in the Anaran anticline (Emami et al. 2010) (see locations in Fig. 3). Other anticlines with more open geometries show smaller amounts of shortening as for example the Mand anticline in the foreland of the NW Fars arc that only shows $3 \%$ shortening (Oveisi, Lavé \& van der Beek, 2007) (see location in Fig. 3).

\section{3.c. Estimates of crustal thickness}

During the last decades, several studies attempted to define the crustal thickness below the Zagros Mountains. Based on Bouguer anomaly maps, Dehghani \& Makris (1984) computed a coarse depth to the Moho map and determined Moho depths around $40 \mathrm{~km}$ in the Mesopotamian foreland and a maximum around $50 \mathrm{~km}$ beneath the Main Zagros Fault near our transect. A more precise modelling of the Bouguer anomaly data conducted by Snyder \& Barazangi (1986) shows a profile near our cross-section with crustal thickening from $40 \mathrm{~km}$ beneath the Mesopotamian foreland to $\sim 60 \mathrm{~km}$ beneath the Main Zagros Fault. More recently, Paul et al. (2006, 2010) published crustal transects across the Zagros Mountains based on receiver function analysis of teleseismic earthquakes to image the Moho (see location in Fig. 1). Their NW transect, located close to our balanced cross-section, shows an undulating base of the crust that increases its depth towards the internal part of the Zagros belt, from an average Moho depth of $42 \pm 2 \mathrm{~km}$ in the Mesopotamian foreland to a maximum Moho depth of $56 \pm 2 \mathrm{~km}$ beneath the southwestern side of the Sanandaj-Sirjan tectonic domain. We use Paul et al.'s (2010) average Moho depths in our cross-section.

\section{3.d. Lithospheric structure}

The lithospheric structure beneath the Zagros Mountains is also little known. Molinaro, Zeyen \& Laurencin 


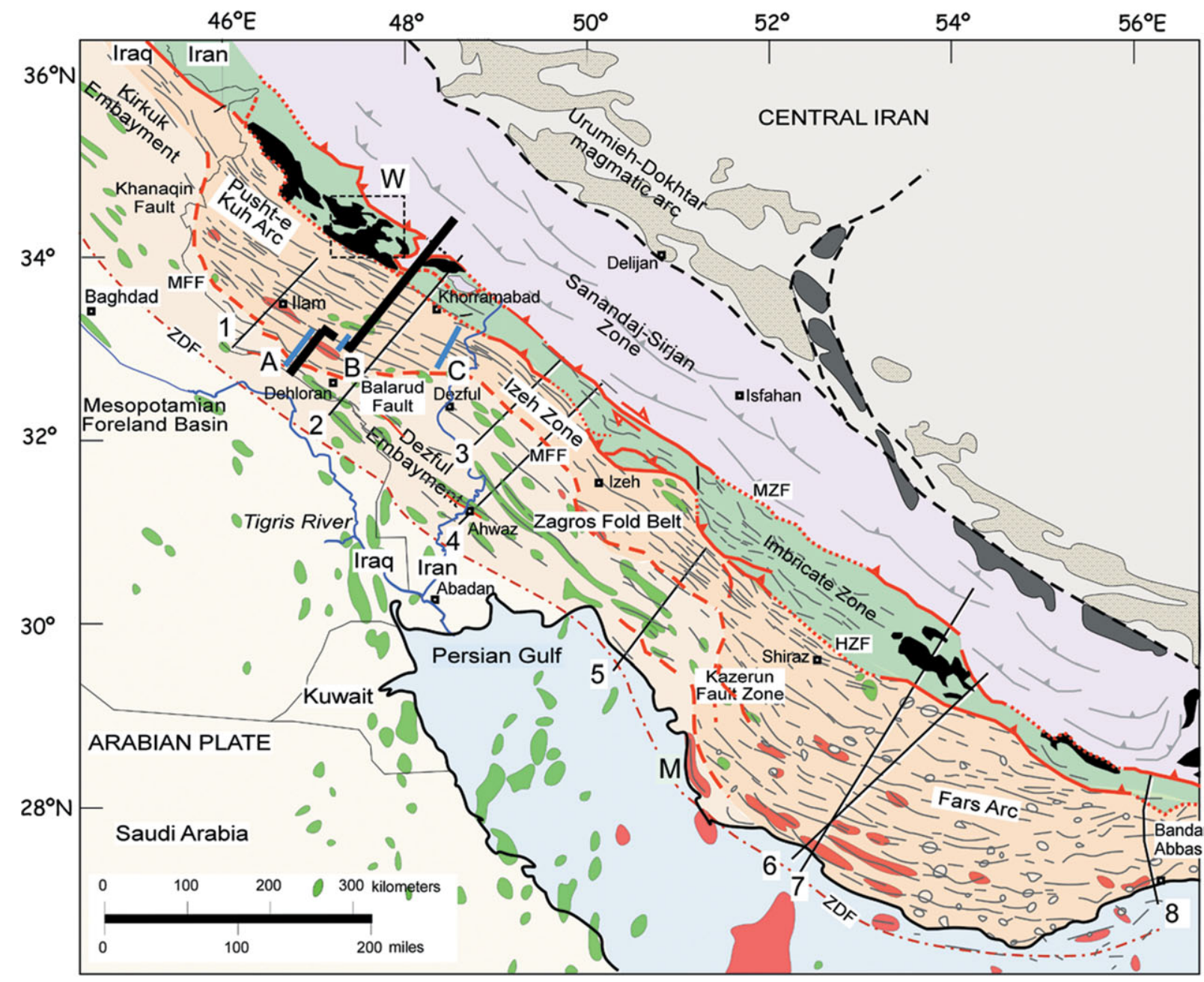

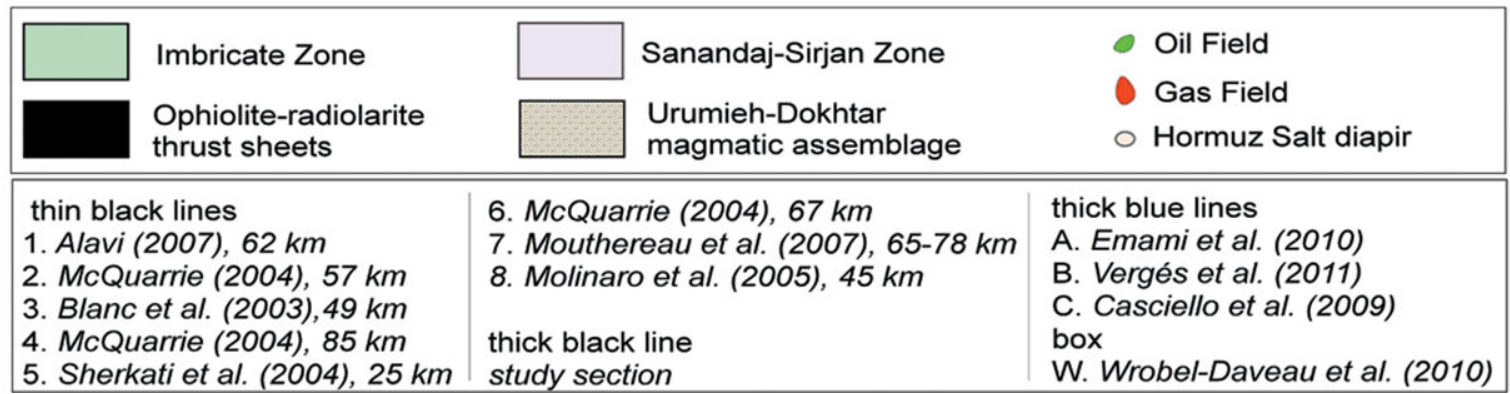

Figure 3. (Colour online) Tectonic map of the Zagros showing the location of the previously published cross-sections with the calculated amount of shortening and the extent of major hydrocarbon fields. The balanced cross-section is marked by the thick black line. M Mand anticline. Dark grey: Naien-Baft ophiolites (Stöklin, 1968).

(2005) presented a lithospheric model of the Fars arc region using geophysical constraints. Their model shows a maximum Moho depth of $52 \mathrm{~km}$ beneath the Zagros Mountains, in agreement with Paul et al. (2006), but a significant reduction of the upper mantle thickness along large parts of the Zagros Fold Belt and the Iranian plateau with respect to the Arabian lithosphere. The upper mantle thinning is interpreted as the effect of the Neo-Tethys oceanic slab break-off occurring in the last few million years (Molinaro, Zeyen \& Laurencin, 2005) that could be confirmed by the lack of a highvelocity anomaly in the mantle beneath Central Iran (Paul et al. 2010).

\section{Balanced crustal cross-section}

The geological cross-section is constructed perpendicular to folding in the Zagros Fold Belt, which displays a regional, constant and fairly rectilinear NE-SW trend in the study region (Fig. 3). This homogeneous trend is parallel to thrust faults bounding the main tectonic domains of the Zagros and is only locally distorted near to, or above, deep oblique structures like the Kazerun Fault (Authemayou et al. 2005; Sepehr \& Cosgrove, 2005) and the Balarud Fault. This regional NE-SW fold trend shows large-scale smooth curving along the Fars arc where the basal detachment is formed by a 

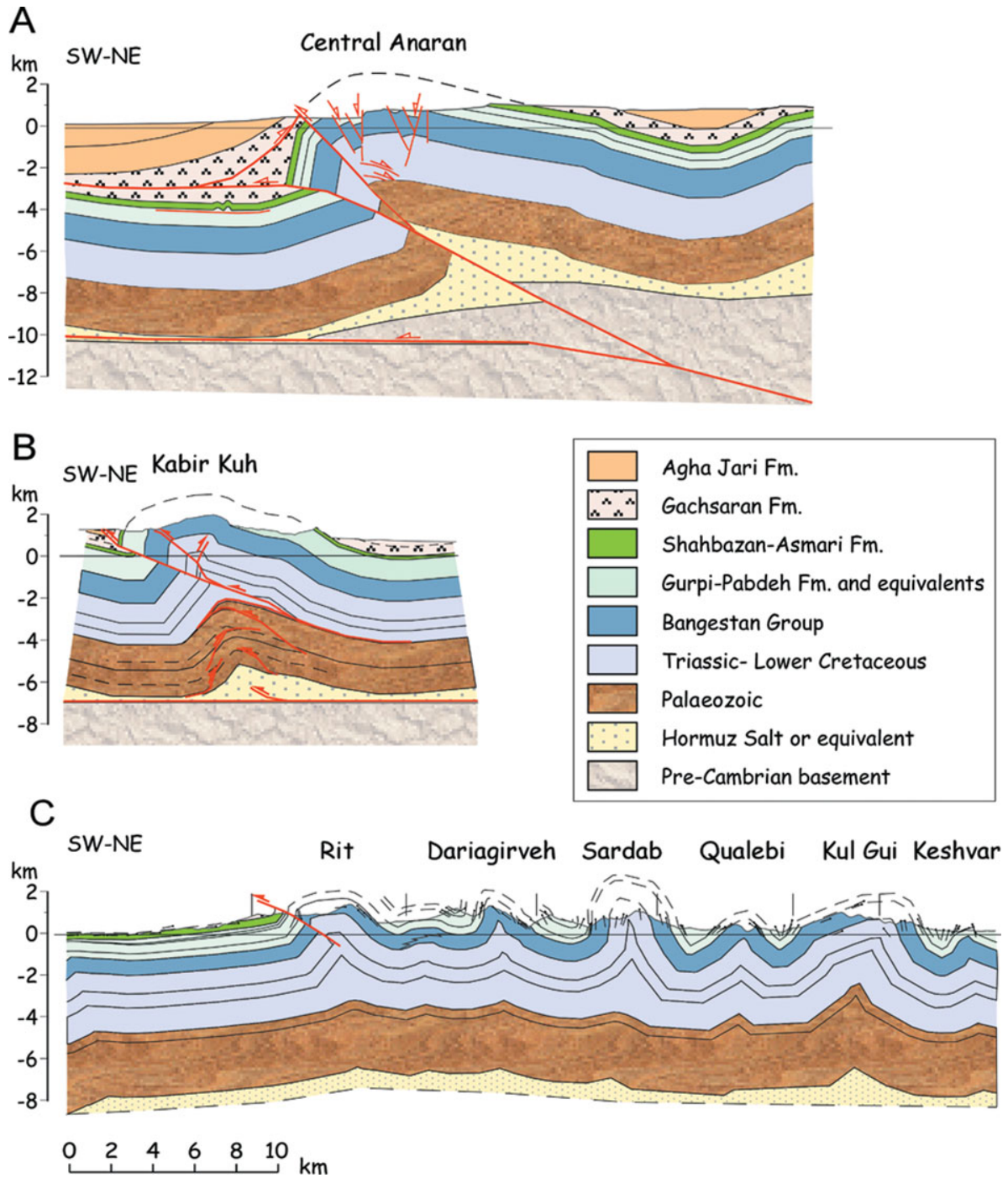

Figure 4. (Colour online) Structural cross-sections showing the style of folding across the studied regional transect (see location in Fig. 3). (a) The front of the Zagros Fold Belt along the Anaran anticline above the Mountain Front Flexure (MFF in Emami et al. 2010); (b) the Kabir Kuh anticline, which represents a multi-detachment fold (Vergés et al. 2010); (c) folds developed in the Upper Cretaceous basinal stratigraphy showing much tighter and upright anticlines (modified from Casciello et al. 2009).

thick level of Hormuz salt (e.g. Edgell, 1996). The trace of the balanced cross-section is thus parallel to the direction of tectonic transport produced by folding, and consequently any shortening calculation accounts for the component of shortening normal to the Suture Zone, which is evidenced by the current seismicity (e.g. Berberian, 1995; Talebian \& Jackson, 2004).

The construction of the balanced crustal crosssection is based on three types of data providing independent information: (1) surface geology for the deformation in the cover rocks across the different tectonic units of the Zagros Fold Belt and geometric models for the basement structure; (2) published receiver function model from Paul et al. (2010) to constrain the geometry of the Moho along the geological cross-section; and (3) a mantle P-wave tomographic model to constrain the boundary between the Arabian and Eurasian lithospheres.

Different solutions have been proposed to construct cross-sections involving both cover and basement rocks but these are not conclusive owing to the lack of good and penetrative seismic lines to image the cover structure at depth. Cross-sections presented in Figure 4 illustrate some of these problems, which were dealt with in two different ways: (a) assuming that shortening is constant through single anticlines, such as the Anaran (Emami et al. 2010) and Kabir Kuh anticlines (Vergés et al. 2011) (Figs 4a and $4 \mathrm{~b}$, respectively); and (b) assuming that shortening is different above and below some of the main detachments and thus must be transferred to the front or to the back by thrusting (e.g. Blanc et al. 2003; Casciello et al. 2009) (Fig. 4c). In addition, wellconstrained early phases of folding in the Pusht-e Kuh arc may introduce variations in shortening, decreasing upwards in the cover stratigraphic succession (e.g. Casciello et al. 2009; Saura et al. 2011).

Remarkably, the study area presents an almost constant structural relief manifested by fairly continuous outcrops of limestone beds corresponding to the top 
of the Upper Cretaceous Bangestan Group and to the Miocene Asmari Formation (Casciello et al. 2009; Vergés et al. 2011). This crucial fact permits the accurate and robust calculation of both deformed and original line lengths of the near top of the Sarvak Formation, which forms the basis for our cover shortening calculation, whatever the interpretation for the deeper structure is.

\section{4.a. Thin- and thick-skinned tectonic structures}

The geological cross-section across the Pusht-e Kuh arc is formed by two segments, linking along the northeastern flank of the Kabir Kuh anticline (Figs 1, 3 ). The section is constrained by field data, geological maps of the National Iranian Oil Company (1:100 000 scale), satellite imagery, a few well data and some seismic reflection profiles available in the southwestern end of the section (Fig. 4). The structure of the Imbricate Zone is modified from cross-sections by Agard et al. (2005) and Wrobel-Daveau et al. (2010) (see location in Fig. 3). In the section we propose deformation in both the cover (thin-skinned) and the basement (thick-skinned). The geometry of the thrust system in the basement attempts to fit the variations in structural relief and the geometry of the cover-basement contact as well as seismicity data. Deformation within the various basement imbricates is assumed to be homogeneous.

The tectonic structure of the Pusht-e Kuh arc is characterized by NW-SE-trending anticlines and synclines showing very little thrusting at the surface and hence predominantly associated with detachment folding (Casciello et al. 2009; Farzipour-Saein et al. 2009; Vergés et al. 2011). These folds display a variety of geometries and sizes, which depend on the distribution of the different detachment levels existing across the sedimentary succession. Similarly to other regions of the Zagros, the present-day seismicity (Berberian, 1995; Engdahl et al. 2006; Tatar, Hatzfeld \& Ghafori-Ashtiany, 2004) and topography strongly point to the involvement of the whole crust in the deformation of the Pusht-e Kuh arc (e.g. Falcon, 1961; Emami et al. 2010; Hatzfeld \& Molnar, 2010; Leturmy, Molinaro \& Frizon de Lamotte, 2010). Our calculations along the geological cross-section show less than $1^{\circ}$ of topographic slope and $0^{\circ}$ for basal detachment angle, in agreement with other similar estimations (McQuarrie, 2004; Ford, 2004). This very low taper angle correlates well to a fold belt detached above an efficient detachment at depth, and is substantiated by the small thrusting contribution (Vergés et al. 2011).

\section{4.b. Crustal geometry of the Arabian plate}

Crustal thickness along the balanced crustal crosssection has been constrained using the results of Paul et al. (2010). In our cross-section, the Moho geometry proposed by these authors is smoothed in order to construct a regularly NE-dipping base of the crust.
In addition, to reconstruct the present-day geometry of the Arabia-Eurasia boundary we use three vertical cross-sections from a recent tomographic model (Villaseñor, Spakman \& Engdahl, 2003; Replumaz et al. 2010) obtained from inversion of P-wave arrival times catalogued in the bulletins of the International Seismological Centre (ISC). This model is an update of the P-wave global tomographic model of Bijwaard, Spakman \& Engdahl (1998) augmented with additional well-located earthquakes at teleseismic and regional distances.

The P-wave model images the boundaries between the different plates involved in the multiple collisions that configured the present-day Arabia-Iran and Caspian Sea domains (Fig. 5). The boundary between Arabia and Iran is well imaged in all the three sections, showing a sharp contrast in the velocity anomalies: the Arabian and the Caspian lithosphere are characterized by high seismic velocities while the Iranian lithosphere is markedly slower. The three tomographic sections also display gradual changes from NW to SE (from section A to section C). The upper mantle of the Arabian plate displays low velocity regions in the northernmost section, in agreement with a warm mantle beneath Anatolia in Turkey, and becomes markedly faster towards the SE (sections B, C). High velocity anomalies of the Arabia domain appear discontinuous in sections $\mathrm{A}$ and B. However, the southeasternmost section C shows a fairly continuous fast anomaly that forms a NE-dipping slab-like feature that could correspond to the Neo-Tethys subducted lithosphere. Finally, based on the P-wave model results along tomographic transect $\mathrm{B}$, we construct the present-day Arabian plate boundary with a relatively sharp contact dipping about $50^{\circ}$ to the NE (Fig. 6).

The characteristics of deformation of the basement rocks included within the proposed crustal boundaries are nowhere observable along the Zagros belt; its interpretation is therefore based on surface observations and on assumptions (Fig. 6). We propose a thrust system that consists of a basal low-angle and NE-dipping crustal-scale thrust (T4), which is in agreement with the geometry of the Mountain Front Flexure and the high and fairly constant topography and structural relief of the entire Pusht-e Kuh arc (Emami et al. 2010). The geometry of the basal thrust is comparable with the one proposed by Mouthereau, Lacombe \& Meyer (2006). The thrust dips with an approximately constant angle of $12-15^{\circ}$ to account for the uplift in the Pushte Kuh arc region and crosses the whole upper crust. This thrust flattens at the cover-basement contact in its SW end (like a fault-bend fold) with a total shortening of $\sim 13 \mathrm{~km}$. Above this basal crustal-scale thrust, a few other thrusts may be defined to match geological observations or the restored cross-section (T3 to T1). Thrust T3 is speculative while thrust T2, beneath the Khorramabad anticline, is inferred by a calculated uplift of about $1300 \mathrm{~m}$ of the northern boundary of the Amiran foreland basin during Paleocene time (Homke et al. 2009). Thrust $\mathrm{T} 1$ is required to lift up the basement 

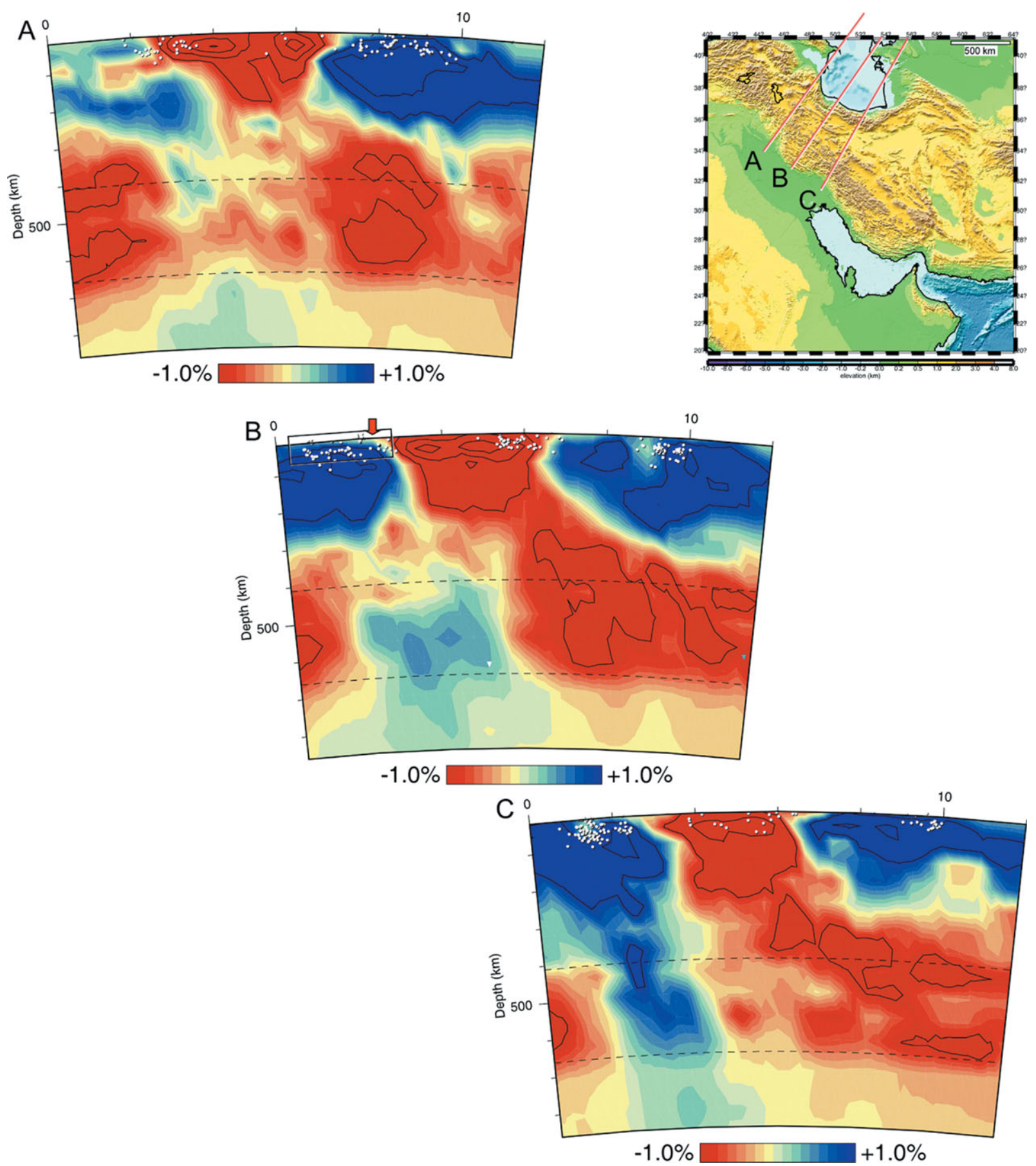

Figure 5. (Colour online) Vertical tomographic transects showing the lithospheric structure across the Zagros mountain belt. The central transect B is coincident with the balanced crustal cross-section indicated by the box area. The sharp contrast between cold and warm lithospheres in the SW side of the section is associated with the Arabian and Eurasian plates, respectively. The box in transect B shows the length of the balanced cross-section. The red arrow shows the position of the Main Zagros Fault at the surface.

underlying the Imbricate Zone where relatively older Mesozoic rocks are exposed. These NE-dipping thrusts may correspond to the inferred thrust faults within the uppermost crystalline basement identified by the clustering of seismic events (e.g. Tatar, Hatzfeld \& Ghafori-Ashtiany, 2004; Hatzfeld et al. 2010).

\section{4.c. Crustal area calculation}

The balanced crustal cross-section allows the determination of the total amount of Arabian crustal area included within the following boundaries (Fig. 6): (a) the foreland pin line, which is the SW vertical limit of the crustal area fixed in the non-deformed Arabian crust at the Iran-Iraq border, $20 \mathrm{~km}$ to the SW of the Mountain Front Flexure; (b) the near-top Sarvak Formation reference level, or its stratigraphic equivalents, representing the topmost boundary of the crustal area; (c) the Moho depth modified after Paul et al. (2010) forming the base of the balanced area; and (d) the Arabian-Iranian plate boundary identified in the seismic tomography, delineating the NE-dipping 


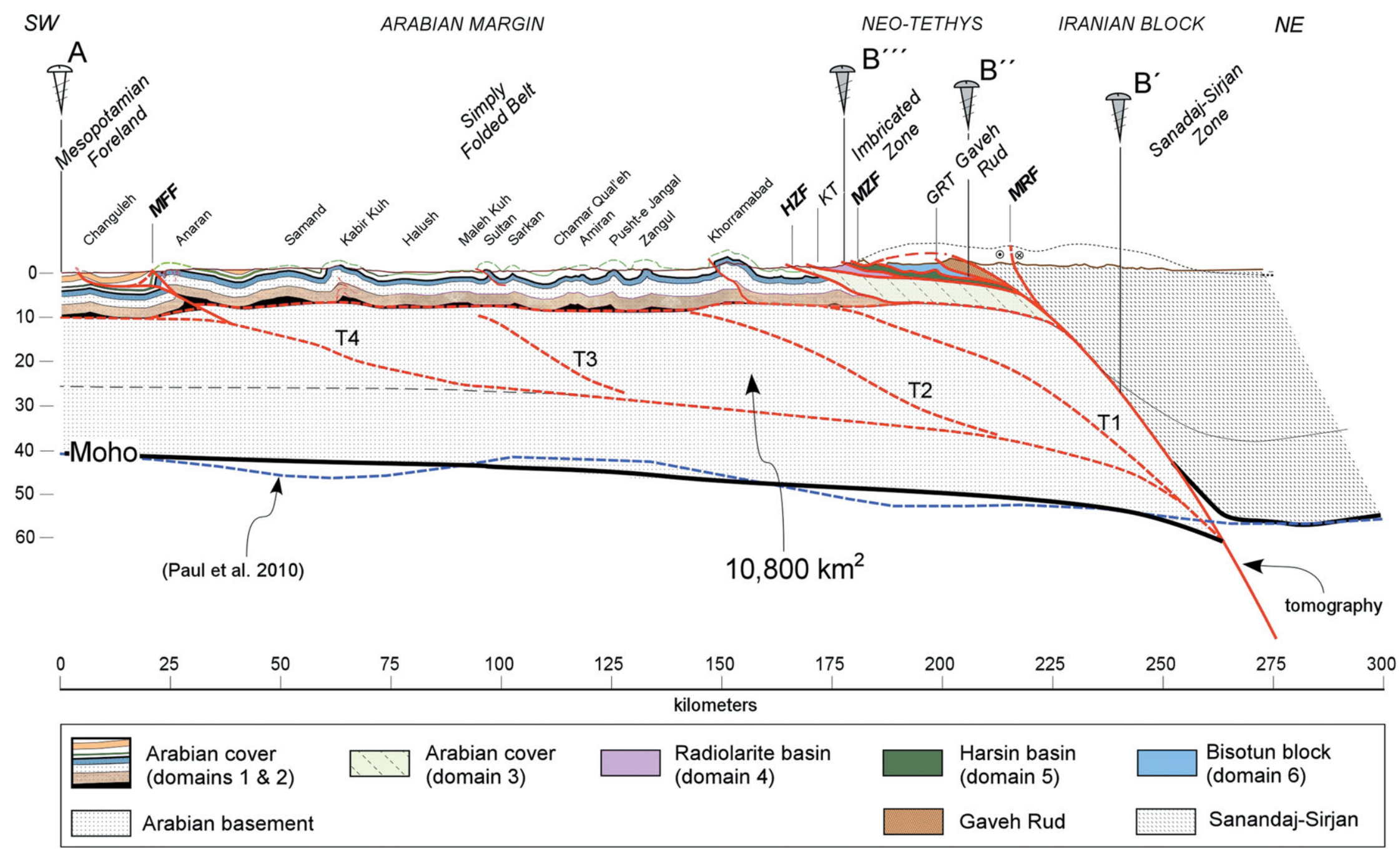

Figure 6. (Colour online) Crustal scale cross-section constrained by surface and sub-surface datasets. The thick black level in the cover succession corresponds to the near top of the Sarvak Formation used to calculate shortening in the Simply Folded Belt. The structure of the inner region is modified from Agard et al. (2005) and Wrobel-Daveau et al. (2010). The base of the crust has been adapted from Paul et al. (2010). The boundary between Arabia and Iran is based on global seismic tomographic studies shown in Figure 5. Mountain Front Flexure - MFF; High Zagros Fault - HZF; Kermanshah Thrust - KT; Main Zagros Fault - MZF; Gaveh Rud Thrust - GRT; and Main Recent Fault - MRF. T1 to T4 are the inferred thrusts in the basement. 
boundary of the calculated area. Within these crustal boundaries the present-day area of the deformed Arabian crust amounts to approximately $10800 \mathrm{~km}^{2}$ from the Moho to the near top of the Sarvak Formation.

The shortening in the cover has been calculated using a line length method taking into account that the near top of the Sarvak Formation is exposed almost continuously along the cross-section. Unfolding of the near top of the Sarvak Formation along the Simply Folded Belt, from the foreland pin line to the footwall of the High Zagros Fault, provides an unfolded length (initial length) of $194 \mathrm{~km}$, whereas the current length of this level is $173 \mathrm{~km}$, which results in a total shortening of $21 \mathrm{~km}(11 \%)$ (Fig. 6).

\section{Reconstruction of the Arabian margin}

The crustal section of the reconstructed Arabian margin images the palaeomargin of Arabia at the time of the top of the Sarvak Formation, that is Turonian time ( $90 \mathrm{Ma}$; Sharp et al. 2010) before the onset of obduction processes. In this reconstruction we assume crustal area conservation during shortening, implying that potential Arabian continent crustal losses during collision processes such as subduction or eclogitization are not accounted for. In addition to area conservation we use the previously defined configuration of the Arabian margin formed by six tectonosedimentary domains. To reconstruct the crustal and lithospheric structure of the palaeogeographic domains prior to the onset of shortening we use the original lengths, if known, of these domains and their sedimentary facies to infer the following palaeobathymetries (Fig. 2): domain 1, mostly covered by neritic limestones with an average palaeoelevation of $-50 \mathrm{~m}$; domain 2 , characterized by pelagic limestones with an average palaeoelevation of $-250 \mathrm{~m}$; domain 3 with an average palaeoelevation of $-500 \mathrm{~m}$; domain 4 along the Radiolarite basin with a proposed palaeoelevation of $-2100 \mathrm{~m}$; domain 5 with serpentinized upper mantle rocks (not accounted for in area balancing); and domain 6 formed by the Bisotun platform carbonates with a palaeoelevation of $-1000 \mathrm{~m}$ in Late Cretaceous times (Fig. 7). Additionally, the Neo-Tethys oceanic domain (domain 7) has been reconstructed at the NE end of the restored section, made up of young oceanic crust with a calculated palaeoelevation of $-3250 \mathrm{~m}$. This latter domain belonging to the Neo-Tethys Ocean is not accounted for in area balancing calculations (Fig. 7).

In the restoration of each tectonosedimentary domain we calculate the crustal thickness that is compatible with the considered palaeobathymetry and estimate its restored length so that the sum of the restored areas of the six Arabian crustal domains equals the area of the present-day balanced section after removing sediments that postdate the Sarvak Formation $\left(10800 \mathrm{~km}^{2}\right.$; Fig. 6). In these calculations we assume local isostasy and pure shear deformation. Furthermore, we define the densities of the crust, lithospheric mantle and asthenosphere, the palaeoelevation of each domain and the undeformed crustal thickness, which is obtained from the present-day crustal thickness $(42 \mathrm{~km})$ minus the thickness of the post-Sarvak sedimentary cover $(6 \mathrm{~km})$ in the Mesopotamian foreland region (Fig. 6).

The steps followed to calculate the restored crustal thickness and length of the tectonosedimentary domains are:

(1) Calculation of the thickness of the undeformed lithospheric column corresponding to domain 1 from its palaeoelevation $(-50 \mathrm{~m})$ and crustal thickness (36 km). According to the formulation by Lachenbruch \& Morgan (1990) the thickness of the lithospheric mantle is given by $\mathrm{H}_{\mathrm{lm}}=\left(\rho_{\mathrm{a}}\left(\mathrm{P}_{\mathrm{wd}}+\mathrm{H}_{0}\right)-\mathrm{H}_{\mathrm{c}}\left(\rho_{\mathrm{a}}-\right.\right.$ $\left.\left.\rho_{\mathrm{c}}\right)\right) /\left(\rho_{\mathrm{a}}-\rho_{\mathrm{m}}\right)$, where $\rho_{\mathrm{c}}, \rho_{\mathrm{m}}$ and $\rho_{\mathrm{a}}$ are the densities of the crust, lithospheric mantle and asthenosphere, respectively; $\mathrm{H}_{c}$ and $\mathrm{H}_{\mathrm{lm}}$ are the thicknesses of the crust and the lithospheric mantle, respectively; $\mathrm{P}_{\mathrm{wd}}$ is the palaeoelevation; and $\mathrm{H}_{0}=2.4 \mathrm{~km}$.

(2) Once we know the lithospheric mantle thickness of domain 1, we can calculate the mean lithospheric density of this domain, which will remain constant under pure shear deformation. We consider a constant lithospheric mantle density of $3250 \mathrm{~kg} / \mathrm{m}^{3}$ and a constant continental crustal density of $2850 \mathrm{~kg} / \mathrm{m}^{3}$ (Christensen \& Mooney, 1995) (Table 1), which is in agreement with a granulitic composition of the lower crust as suggested by Mouthereau, Lacombe \& Meyer (2006). The variation of the total lithospheric thickness of a given domain related to the variation of its palaeobathymetry with respect to domain 1 will be given by $\Delta \mathrm{H}_{1}=\left(\left(\rho_{\mathrm{a}}-\rho_{\mathrm{w}}\right) /\left(\rho_{1}-\rho_{\mathrm{a}}\right)\right) \Delta \mathrm{H}_{\mathrm{w}}$, where $\rho_{\mathrm{w}}$ and $\rho_{1}$ are the densities of sea-water and lithosphere, respectively; and $\Delta \mathrm{H}_{1}$ and $\Delta \mathrm{H}_{\mathrm{w}}$ are the variations of lithospheric thickness and palaeobathymetry of a given domain with respect to domain 1 , respectively.

(3) With these data we calculate the beta factors for each domain as $\beta_{\mathrm{n}}=\mathrm{H}_{1}{ }^{\mathrm{n}} / \mathrm{H}_{1}{ }^{1}$ and hence, the restored crustal thickness as $\mathrm{H}_{\mathrm{cn}}{ }^{\mathrm{r}}=\mathrm{H}_{\mathrm{cl}} / \beta_{\mathrm{n}}$, where $\beta_{\mathrm{n}}$ is the beta factor of the n-domain; $\mathrm{H}_{1}{ }^{\mathrm{n}}$ and $\mathrm{H}_{1}{ }^{1}$ are the restored lithospheric thicknesses of the n-domain and domain 1, respectively; and $\mathrm{H}_{\mathrm{cn}}{ }^{\mathrm{r}}$ and $\mathrm{H}_{\mathrm{cl}}$ are the crustal thicknesses of the restored n-domain and the undeformed domain 1 , respectively.

(4) Finally, the condition of area conservation implies that $\Sigma \mathrm{S}_{\mathrm{c}}{ }^{\mathrm{n}}=\mathrm{S}_{\text {balanced }}=\Sigma \mathrm{H}_{\mathrm{cn}}{ }^{\mathrm{r}} * \mathrm{~W}_{\mathrm{n}}$, where $\mathrm{S}_{\mathrm{c}}{ }^{\mathrm{n}}$ are the areas of each restored tectonosedimentary crustal domain; $\mathrm{S}_{\text {balanced }}$ is the area of the present-day balanced crustal cross-section $\left(10800 \mathrm{~km}^{2}\right)$; and $\mathrm{W}_{\mathrm{n}}$ is the restored length of each tectonosedimentary crustal domain.

We have considered only two lithospheric layers, the crust and the lithospheric mantle, and their average densities. Under pure shear deformation conditions this suffices for our isostatic calculations. Table 1 summarizes the input parameters and the restored thickness, length and area obtained for each tectonosedimentary domain defined in the restoration (Fig. 7). 


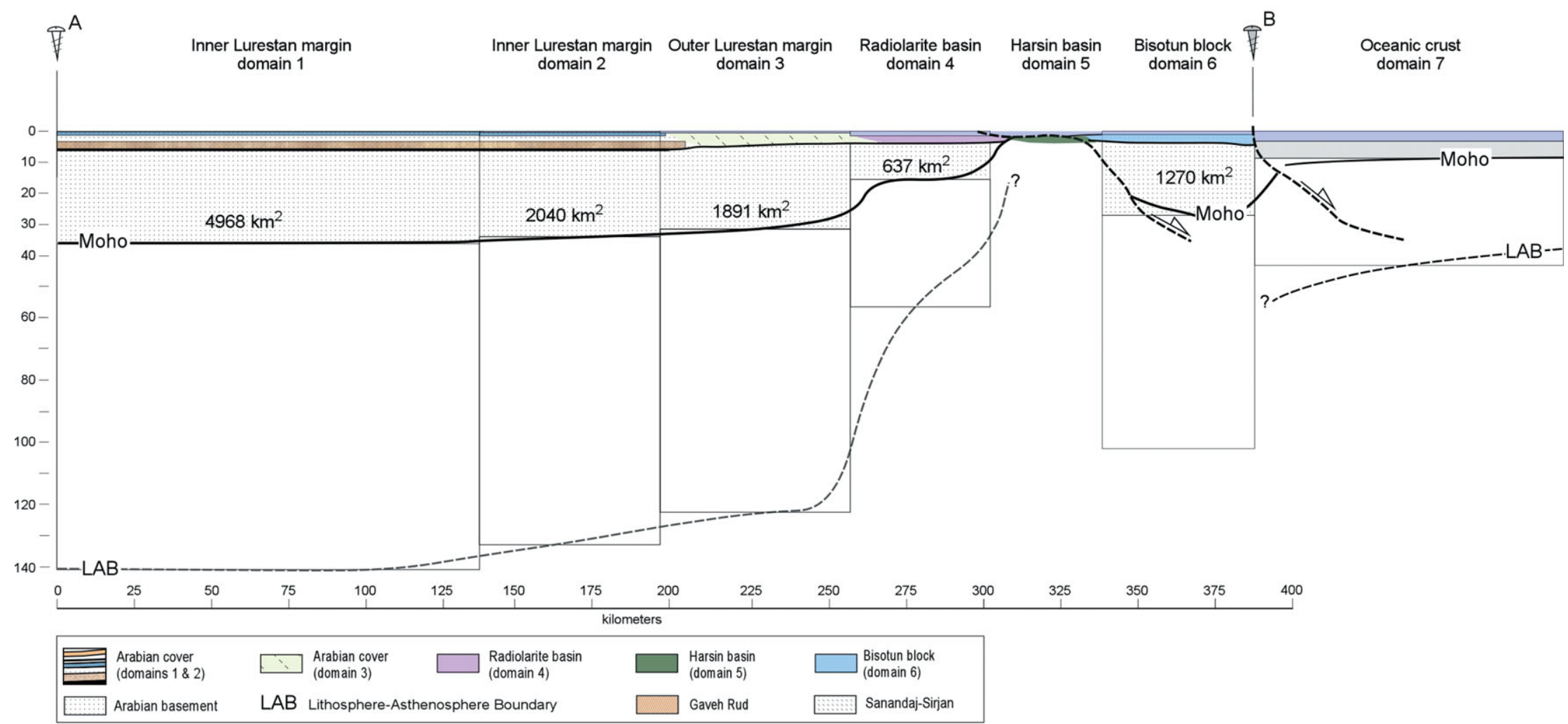

Figure 7. (Colour online) Restored crustal cross-section showing the reconstructed Arabian margin during Late Cretaceous time. The reconstructed Arabian margin is built of six different palaeogeographic domains to the SW of the Neo-Tethys oceanic domain 7 (not accounted for in the area balancing). The dotted areas with area quantity correspond to the crustal structure calculated from the model. The larger white areas correspond to the lithospheric mantle. The Moho and the LAB (lithosphere-asthenosphere boundary) shown by the thick and dashed thick lines, respectively, are tentative. The large normal faults along the NE boundaries of domains 5 and 6 are speculative. 
Table 1. Table showing the parameters used in the reconstruction of the Arabian margin in Late Cretaceous time, as well as the widths and palaeobathymetries for each of the reconstructed palaeogeographic domains

\begin{tabular}{|c|c|c|c|c|c|c|c|}
\hline \multirow{3}{*}{$\begin{array}{l}\text { Restored domains } \\
\text { Tectonic units }\end{array}$} & Domain 1 & Domain 2 & Domain 3 & Domain 4 & Domain 5 & Domain 6 & \multirow{2}{*}{$\begin{array}{l}\text { Domain } 7 \\
\begin{array}{l}\text { Neo-Tethys } \\
\text { oceanic crust }\end{array}\end{array}$} \\
\hline & \multicolumn{2}{|c|}{ Simply Folded Belt } & \multicolumn{4}{|c|}{$\begin{array}{c}\text { Imbricate Zone } \\
\text { Kermanshah Complex }\end{array}$} & \\
\hline & $\begin{array}{l}\text { Inner Lurestan } \\
\text { margin }\end{array}$ & $\begin{array}{l}\text { Inner Lurestan } \\
\text { margin }\end{array}$ & $\begin{array}{c}\text { Outer Lurestan } \\
\text { margin }\end{array}$ & $\begin{array}{l}\text { Radiolarite } \\
\text { basin }\end{array}$ & $\begin{array}{l}\text { Harsin } \\
\text { Basin }\end{array}$ & $\begin{array}{l}\text { Bisotun } \\
\text { Block }\end{array}$ & $\begin{array}{l}\text { Neo-Tethys } \\
\text { oceanic crust }\end{array}$ \\
\hline Width (km) & 136 & 58 & 62 & 45 & 35 & 49 & \\
\hline Palaeoelevation (m) & -50 & -250 & -500 & -2100 & & -1000 & -3250 \\
\hline Crustal thickness $-\mathrm{H}_{\mathrm{c}}(\mathrm{km})$ & 36 & 34 & 31 & 14 & & 26 & 5.5 \\
\hline Upper mantle thickness $-\mathrm{H}_{\mathrm{lm}}(\mathrm{km})$ & 105 & 99 & 91 & 41 & & 75 & 34.5 \\
\hline Lithospheric thickness $-\mathrm{H}_{1}(\mathrm{~km})$ & 141 & 132 & 122 & 56 & & 101 & 40 \\
\hline$\beta$ factor & 1 & 1 & 1 & 3 & & 1 & \\
\hline Variation of lithospheric thickness - & & & & & & & \\
\hline$\Delta \mathrm{H}_{1}$ & 0 & 8 & 19 & 85 & & 39 & \\
\hline
\end{tabular}

Sea-water density, $\rho_{\mathrm{w}}=1030 \mathrm{~kg} / \mathrm{m}^{3}$; asthenosphere density, $\rho_{\mathrm{a}}=3200 \mathrm{~kg} / \mathrm{m}^{3} ;$ lithospheric mantle density, $\rho_{\mathrm{m}}=3250 \mathrm{~kg} / \mathrm{m}^{3} ; \mathrm{crust}$ density, $\rho_{\mathrm{c}}=2850 \mathrm{~kg} / \mathrm{m}^{3}$.

The length and palaeobathymetry estimates for domains 1 and 2 are well constrained since the cover is fully exposed along the Simply Folded Belt in the study area. The unfolding of the near-top Sarvak Formation reference level along the Simply Folded Belt unit gives a restored length (initial length) of $194 \mathrm{~km}$. This unfolded length is used in combination with palaeogeographic maps (Koop \& Stoneley, 1982), which show that the carbonate platforms and the basinal areas occupy restored lengths of about $136 \mathrm{~km}$ and $58 \mathrm{~km}$, respectively (lengths of domain 1 in the SW and domain 2 in the NE; Fig. 7; Table 1). Using mean palaeoelevations of $-50 \mathrm{~m}$ for domain 1 and $-250 \mathrm{~m}$ for domain 2, the calculated crustal thicknesses (from near top of the Sarvak Formation to base of the crust) are $36 \mathrm{~km}$ and $34 \mathrm{~km}$, respectively. The sum of these two well-constrained areas with relatively shallow palaeogeographic domains is over $6850 \mathrm{~km}^{2}$, which represents almost $65 \%$ of the total calculated area of the balanced crustal cross-section (Fig. 6). The lithospheric thickness obtained for the undeformed Arabian plate is $\sim 141 \mathrm{~km}$, in good agreement with global estimates of Proterozoic terranes (PoudjomDjomani et al. 2001; Artemieva, 2006). Consequently, the average density of the lithospheric mantle is set to $3250 \mathrm{~kg} / \mathrm{m}^{3}$, corresponding to stable regions according to Lachenbruch \& Morgan (1990) (Table 1).

The reconstruction of domain 3 , corresponding to the Outer Lurestan Margin, is achieved by measuring the length of the Imbricate Zone beneath the Kermanshah thrust, corresponding to approximately $56 \mathrm{~km}$ (Fig. 6). If we assume $11 \%$ shortening for this area (equal to the Simply Folded Belt result but clearly underestimated) we obtain a presumed original length of $62 \mathrm{~km}$ for domain 3. We assume about $-500 \mathrm{~m}$ as the mean palaeoelevation of the Upper Cretaceous rocks in domain 3 and obtain a crustal thickness of $\sim 31 \mathrm{~km}$. The total length of domain 4, the Radiolarite basin, is constrained by the cross-sections and maps presented by Wrobel-Daveau et al. (2010) accounting for a minimum of $37 \mathrm{~km}$ (Fig. 6). For this domain we assume an internal shortening of $20 \%$ (based on WrobelDaveau et al. 2010) resulting in an original length of $45 \mathrm{~km}$ (Fig. 7; Table 1). A palaeobathymetry of $2100 \mathrm{~m}$ for the deep water radiolarites results in an estimate of crustal thickness of $\sim 14 \mathrm{~km}$ for domain 4 . The proposed upper mantle Harsin basin, i.e. domain 5 (Wrobel-Daveau et al. 2010), is not accounted for in the crustal area calculation. Its minimum length of $35 \mathrm{~km}$ is calculated from geological cross-sections by Wrobel-Daveau et al. (2010) and has a direct impact in shortening calculations. The total unfolded length of domain 6 (Bisotun block) is $49 \mathrm{~km}$, which together with palaeo-water depths of about $1000 \mathrm{~m}$ results in an original crustal thicknesses of $26 \mathrm{~km}$.

The Tethys oceanic domain (domain 7) has been constructed considering a half-space cooling model for young oceanic crust (Turcotte \& Schubert, 2002) resulting in $-3250 \mathrm{~m}$ of palaeoelevation, and $5.5 \mathrm{~km}$ and $40 \mathrm{~km}$ of crustal and lithospheric thickness, respectively (Fig. 7; Table 1). It is important to remember that this unit is never used for the mass conservation calculations in our cross-sections.

Employing these crustal thickness results we obtain a restored area calculation of $3847 \mathrm{~km}^{2}$ for the areas corresponding to domains 3, 4, 5 (no area) and 6 . The sum of crustal areas of restored domains 1 to 4 and 6 gives a total of $10708 \mathrm{~km}^{2}$, which almost equals the $10800 \mathrm{~km}^{2}$ determined from the balanced crustal cross-section. Therefore, the total length of the reconstructed Arabian margin, from the pin line in the foreland to the Neo-Tethys oceanic domain 7 is $385 \mathrm{~km}$, including the $35 \mathrm{~km}$ length of the Harsin basin in domain 5 (Fig. 7).

The Arabian margin illustrated in the restored crosssection presents a complex structure that resembles the reconstruction by Wrobel-Daveau et al. (2010). The Arabian crust shows a progressive thinning from $36 \mathrm{~km}$ to about $14 \mathrm{~km}$ under the Radiolarite basin, adjacent to upper mantle rocks of the Harsin basin (Fig. 7). The Bisotun crustal block, to the NE of the 
Harsin basin, is thicker again and marks the boundary with the Neo-Tethys oceanic domain. These thinned domains were certainly extended by normal faults; however, these have not been identified in the field and therefore the ones shown in the restored crosssection are conjectural. In addition, there are no data to distinguish the lower crust beneath the Zagros and thus our balanced and restored cross-sections show an undifferentiated crust. However, it is reasonable to assume that highly extended domains may have a thinned lower crust or none at all (e.g. domain 4 and to some extent domain 6 as indicated in the restored cross-section of Fig. 7).

The base of the lithosphere roughly parallels the topography of the base of the crust and shows a relatively abrupt mantle that becomes thinner across domain 4 and very thin in the Harsin basin. However, it is important to remember that the main objective of this work is to provide a quantitative estimate of the original length of the continental Arabian margin while the precise geometry of the margin still needs to be constrained by further work on sedimentary facies characterization, on their estimated palaeobathymetry, and on recognition of extensional structures related to the margin formation. These further studies will permit the reconstruction of the Arabian margin with a more accurate geometry (Fig. 7).

\section{Discussion: implications of balanced and restored cross-sections for the past and present-day structure of the Zagros}

Three main subjects are discussed in this Section: (1) shortening estimates based on the direct comparison between the present-day crustal balanced cross-section and the reconstructed margin during Late Cretaceous time; (2) comparison of our results with recently published interpretations based on geological and seismic data; and (3) reviewing the significance of the Zagros thrusts using the comparison between balanced and restored crustal cross-sections (Fig. 8).

\section{6.a. Shortening estimates using balanced and restored cross-section comparison}

The comparison between balanced and restored crosssections is straightforward and allows for direct estimations of shortening using the fixed pin line located in the Mesopotamian foreland, ahead of the Mountain Front Flexure, as the leading reference (pin line A; Fig. 8). The trailing pin line of the Arabian continental crust is located along the northeastern boundary of the Bisotun block (domain 6) in the reconstructed cross-section (pin line B), while in the present cross-section it is located in the trailing part of the same basement unit (pin line B') (Fig. 8). The length of the reconstructed Arabian continental crust, between pin lines A and B is $385 \mathrm{~km}$, whereas the present length of the deformed Arabian continental crust, between pin lines $\mathrm{A}_{\text {and }} \mathrm{B}^{\prime}$, is $236 \mathrm{~km}$ (Fig. 8). The resultant $149 \mathrm{~km}$ between pin lines $\mathrm{B}$ and $\mathrm{B}^{\prime}$ correspond to the crustal shortening of the Arabian plate (Fig. 8). This result indicates that the original Arabian continental-oceanic boundary (pin line B) was located $\sim 169 \mathrm{~km}$ to the NE of the present trace of the Main Recent Fault (MRF in Fig. 6). Besides, if we use a trailing pin fixed to the sedimentary cover (pin line B") of the northeastern end of the Bisotun block, the resultant crustal shortening increases to about $180 \mathrm{~km}$ (Fig. 8).

These new estimates of shortening (149 and $180 \mathrm{~km}$ ) based on the area balanced crustal cross-section are much larger than previous calculations obtained using only surficial structural information (Fig. 3). A significant part of this shortening is probably concentrated in the High Zagros rather than in the Simply Folded Belt, where folds are detached and there are no indications of large thrusts breaching the surface. As stated above, the $149 \mathrm{~km}$ of Arabian basement shortening includes the overall effects of the Arabia-Eurasia collision including the final emplacement of the Gaveh Rud and Sanandaj-Sirjan Zone after the completion of the NeoTethys closure. The displacements of the Gaveh Rud and the Sanandaj-Sirjan tectonic units above their basal thrusts are, however, not included in the calculated shortening (GRT: Gaveh Rud Thrust and MZF: Main Zagros Fault; Figs 2, 8).

The prevailing palaeogeographic model for the Arabian margin before the reconstruction by WrobelDaveau et al. (2010), which is adopted in this paper, consisted of an Arabian margin without the Harsin sub-oceanic basin (e.g. Braud, 1987; Agard et al. 2005). In this model, the ophiolites of the Kermanshah Complex were interpreted as scraped off from the Neo-Tethys oceanic crustal domain. Even though the palaeogeographic reconstruction used in this paper is based on well-constrained field relationships between different rock assemblages and tectonic slices of the Kermanshah Complex (Wrobel-Daveau et al. 2010), we also discuss the potential shortening estimates employing a configuration lacking the Harsin basin. For this purpose, new pin lines are located in the southwestern outcrop of the ophiolites in the deformed cross-section that restores along the continentaloceanic boundary in the undeformed cross-section (pin lines $\mathrm{B}^{\prime \prime \prime}$ in Fig. 8). By comparing the present and past positions of these ophiolitic pin lines the shortening estimate is $171 \mathrm{~km}$ after subtracting the $35 \mathrm{~km}$ width of the Harsin sub-oceanic basin, which is not accounted for in this alternative reconstruction. Interestingly, the $171 \mathrm{~km}$ result is not very dissimilar from the $180 \mathrm{~km}$ of shortening obtained from our preferred reconstruction.

The difference in shortening between the $180 \mathrm{~km}$ (or $171 \mathrm{~km}$ ) determined in the sedimentary cover and the $149 \mathrm{~km}$ obtained for the basement of the Arabian continental crust may be explained by considering a significant tectonic decoupling between the sedimentary cover and the basement along a major detachment along the Hormuz salt or equivalent (Fig. 8). Following this interpretation, the cover rocks may have approximately $31 \mathrm{~km}$ of extra shortening with respect to the basement 


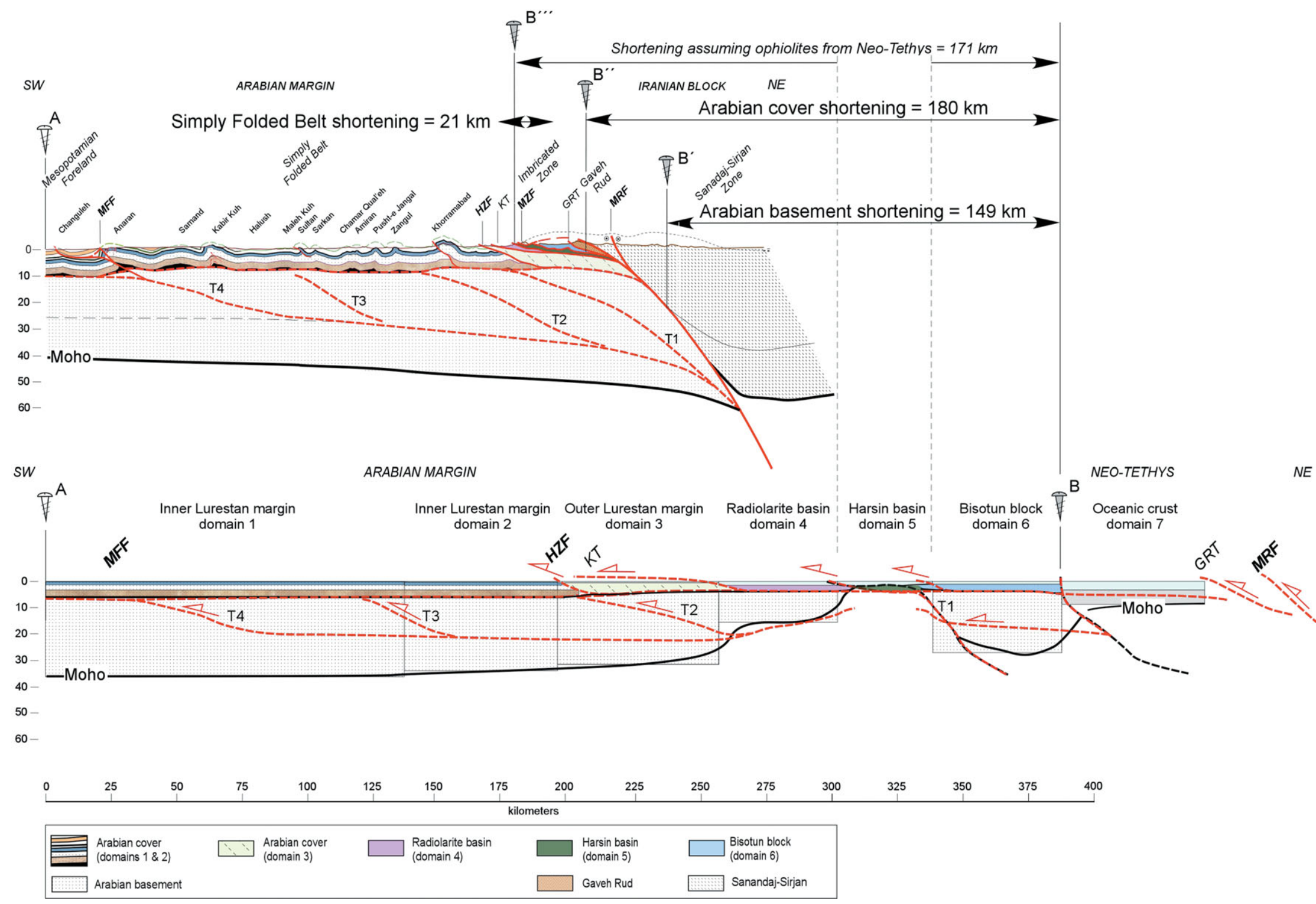

Figure 8. (Colour online) Balanced and restored cross-sections with estimates of shortening and thrust geometries. In the restored cross-section, the positions of the Gaveh Rud Thrust (GRT) and Main Recent Fault (MRF) to the NE of the Neo-Tethys domain are only relative. Shortening assuming the classical alternative with ophiolites belonging to the Neo-Tethys oceanic domain is calculated from pin lines B to B"' but subtracting the length of the Harsin basin domain 5 (not accounted for in that reconstruction). MFF - Mountain Front Flexure; HZF - High Zagros Fault; KT - Kermanshah Thrust; MZF - Main Zagros Fault. 
units. This difference in shortening was possibly transferred along the cover succession during the Late Cretaceous oceanic obduction before the onset of the Arabian basement deformation.

A total shortening of $180 \mathrm{~km}$ is used to calculate long-term average rates of shortening since Turonian times (initial age for the tectonic emplacement of the Kermanshah Complex to present providing a mean value of $\left.2.0 \mathrm{~mm} \mathrm{yr}^{-1}(180 \mathrm{~km} / 90 \mathrm{Ma})\right)$. The Arabian margin, however, did not shorten at this regular rate. Several well-documented periods of reduced tectonic activity or quiescence occurred throughout the Zagros orogeny as highlighted by Homke et al. (2010) and references therein.

\section{6.b. Comparison with previous qualitative Arabian margin reconstructions}

Estimates of shortening in this paper are much higher than all previous determinations owing to the different method of calculation (regional crustal area versus more local line-length balancing). Recent works, however, have been pointing out the misfit between the apparently low estimates of shortening and the longterm convergence rates of $8-10 \mathrm{~mm} \mathrm{yr}^{-1}$ within the Zagros Fold Belt (Tatar et al. 2002; Nilforoushan et al. 2003), suggesting tentative shortening amounts of 150-230 km (e.g. Fakhari et al. 2008; Gavillot et al. 2010). McQuarrie et al. (2003) also suggested a large potential length of the Arabian margin, which would directly result in higher shortening, to fit both map reconstructions and the presumed Miocene timing of the Arabia-Eurasia collision.

There are various papers that deal with the post Late Cretaceous evolution of the Arabian margin employing the available geological datasets (e.g. Stoneley, 1990; Alavi, 1994; Hessami et al. 2001; Mohajjel, Fergusson \& Sahandi, 2003; Agard et al. 2005, 2006; Mouthereau et al. 2007; Piryaei et al. 2010). However, most of these reconstructions are qualitative and thus difficult to compare with our results. Mouthereau et al. (2007) (see the location of the cross-section in Fig. 3 number 7) showed a semi-quantitative reconstruction of the Arabian margin across the Fars region of Iran based on an estimated shortening of $65-78 \mathrm{~km}$ across the entire Zagros and thus proposing a $125 \mathrm{~km}$ wide reconstructed Arabian margin. The comparison between these two segments of the Arabian crust is not straightforward and potential lateral variations of the Arabian margin width need further investigation.

The most recent crustal transect across the NW Zagros has been produced by Paul et al. (2010) based on receiver function analysis of teleseismic earthquakes to image the Moho. This crustal transect closely coincides with our cross-section, thus is directly comparable (see location in Fig. 1). Their seismic results depict a low velocity layer dipping less than $10^{\circ}$ to the NE, which is interpreted as a low-angle crustalscale thrust fault. This low-angle reflector apparently corresponding to the surface expression of the Main
Zagros Fault is interpreted as the suture between the Arabian and Iranian plates. In this interpretation the Arabian crust beneath the large-scale crustal thrust terminates approximately $280 \mathrm{~km}$ to the NE of the trace of the Main Zagros Fault and close to the southern boundary of the Alborz Mountains. This implies a large crustal duplication above a very low-angle thrust with $300 \mathrm{~km}$ of tectonic thrusting (Paul et al. 2010; Hatzfeld \& Molnar, 2010). Although not discussed by the authors, the assumption of a continuous undeformed low-angle thrust implies that most or all the shortening is concentrated in its hangingwall (the Iranian block). The NE-dipping low-angle boundary between Arabia and Iran seems difficult to reconcile with both presented tomographic results and with existing orogenic models in which sutures are steep and strong deformation is observed in both the upper and the lower plates.

\section{6.c. Significance of different thrusts in the Zagros Fold Belt}

The area balanced and restored cross-sections offer the opportunity to propose hints on the geometry of the thrust systems and to discuss how this compressional system modified the previous configuration of the Arabian margin (Fig. 8). The Zagros contractional structures may be grouped into cover and basement thrust systems, which are mostly decoupled from each other. The cover thrust system is mostly controlled by the basal detachment along the infra-Cambrian Hormuz salt or equivalent layers and by other regionalscale detachment levels (e.g. Casciello et al. 2009; Farzipour-Saein et al. 2009; Vergés et al. 2011). The basement thrust system thickens the crust below the cover-basement interface and seems to be responsible for most of the large historical earthquakes in the study area (Fig. 1). Decoupling along the cover-basement contact is observed when comparing the position of basement and sedimentary cover of the Bisotun block in the restored cross-section and its current position (Fig. 8). This decoupling is typical of orogenic systems in which the cover-basement contact is an extremely weak layer like in the Pyrenees, the Betics, the Alps and other fold-thrust belts. These fold belts are deformed by large crustal thrusts with ramp-flat geometries in which the thrust ramp in the basement may be separated by a few tens of kilometres from the deformation front, located ahead in the sedimentary cover above flat segments of the same thrust.

The largest thrust affecting the rocks of the Arabian plate is the basal thrust of the Kermanshah Complex carrying numerous imbricates that include the Bisotun cover rocks (domain 6), thin slivers of serpentinized upper mantle rocks from the Harsin basin (domain 5) and radiolaritic rocks from the Radiolarite basin (domain 4) (Kermanshah Thrust in Figs 2, 6, 8). The Kermanshah Thrust displays a very irregular cartographic trace, indicating it is a low-angle structure (flat geometry). This low-angle and large-displacement thrust system favours its interpretation as being formed 
in relation to a southwestwards advancing tectonic wedge located ahead of the main thrust of oceanic obduction. Blocks of the stretched Arabian margin, serpentinized upper mantle rocks and radiolarites were progressively piled up in this accretionary prism and thrusted over the carbonate ramps and platforms of the Arabian margin (Outer Lurestan margin; domain 3) (Mishrif/Sarvak Formation in the Zagros and Natih Formation in Oman; e.g. Ricou, Braud \& Brunn, 1977; Braud, 1987; Ravaut et al. 1997). As already discussed, the hangingwall of the Kermanshah thrust presents about $31 \mathrm{~km}$ of extra shortening with respect to the Arabian basement, interpreted as occurring during obduction of the Neo-Tethys oceanic crust (domain 7), which started at the Cenomanian-Turonian boundary (Sengör, 1990) about $93.5 \mathrm{Ma}$ or slightly earlier (Berthier et al. 1974), and was fossilized in the study area by Amiran siliciclastic deposits, which can be as old as Campanian (>70.6 Ma; Saura et al. 2011).

The cover sequences of the Imbricate Zone (Outer Lurestan margin, domain 3 in the restored crosssection, Fig. 7) were also involved in contractional deformation forming imbricates when the Kermanshah Complex was almost emplaced (e.g. Mohajjel, Fergusson \& Sahandi, 2003; Nemati \& Yassaghi, 2010; Wrobel-Daveau et al. 2010). The emplacement of these imbricates propitiated folding of the previously emplaced units, including the Kermanshah thrust, and break-through and out-of-sequence thrusting that make the study of these areas very complicated (e.g. Agard et al. 2005). Synchronously to the emplacement of the Kermanshah Complex, the Arabian plate flexed down producing the Amiran foreland basin that filled up with siliciclastic sequences (e.g. Homke et al. 2009; Saura et al. 2011). The frontal thrust of this sequence of tectonic imbricates is the High Zagros Fault (HZF) involving the entire sedimentary succession, including the infra-Cambrian Hormuz salt along several segments of its trace (e.g. Gavillot et al. 2010). Although it is difficult to obtain the accurate timing of deformation of the Imbricate Zone, the SW migration of the Amiran basin depocentre by $80 \mathrm{~km}$ from Campanian to late Early Eocene times appears directly related to the advancement of the Kermanshah thrust system and Imbricate Zone, occurring at an average rate of $\sim 5 \mathrm{~mm} \mathrm{yr}^{-1}$, with variable rates through time (Saura et al. 2011). Deformation of the Amiran foreland basin and its substratum was also coeval to its filling as demonstrated by the thickness variations of the basin infill (Casciello et al. 2009, Saura et al. 2011) and the $1.3 \mathrm{~km}$ uplift of the basin's NE side during its evolution (Homke et al. 2009).

The formation of the spectacular folds in the Lurestan region and in other areas of the Zagros Simply Folded Belt is a recent expression of the Zagros orogeny; however, it only accounts for about $21 \mathrm{~km}$ of shortening, most of it occurring during Miocene and Pliocene times (Homke et al. 2004; H. Emami, unpub. Ph.D. thesis, Univ. de Barcelona, 2008;
Fakhari et al. 2008; Khadivi et al. 2010; Gavillot et al. 2010). This shortening was approximately concurrent to the emplacement of both the Gaveh Rud (above the Gaveh Rud thrust) and the Sanandaj-Sirjan tectonic units above the Main Zagros Fault (Figs 6, 8). The emplacement of these two large tectonic units above the already emplaced Kermanshah Complex reflects major out-of-sequence thrusting during the Zagros collision. Interestingly, the High Zagros Fault appears to be a long-lived thrust, active for several million years and partly coeval to the growth of the Simply Folded Belt as confirmed by Gavillot et al. (2010). Somewhat after the development of folding, the entire Lurestan province uplifted by several kilometres above the blind thrust located beneath the Mountain Front Flexure (Falcon, 1961; Emami et al. 2010), which transferred part of its shortening to cover structures located in the less deformed foreland basin in Iraq.

The northwards convergence of Arabia and Eurasia triggered the formation of the Main Recent Fault (MRF), a large dextral strike-slip fault that re-activated segments of the Main Zagros Fault (Talebian \& Jackson, 2002) and cut the previously emplaced Gaveh Rud and Sanandaj-Sirjan basal thrusts (GRT and MZF, respectively). The relatively rectilinear trace of the fault seems to indicate a steep geometry at depth, which is in agreement with the steep limit of the Arabian crust as shown in the balanced cross-section (Fig. 8).

The sequence of deformation in the Zagros is thus older in the inner parts of the chain and becomes progressively younger in the external Simply Folded Belt, covering the Late Cretaceous to Pliocene time span. This protracted shortening is the result of oceanic obduction and subsequent continent-continent collision separated by periods of tectonic quiescence of the foreland basin, indicating a complex ArabianEurasian evolution (e.g. Barrier \& Vrielynck, 2008; Homke et al. 2010). The age of the continental collision is reflected in Early Miocene growth strata, which were dated by different methods in both the Simply Folded Belt (e.g. H. Emami, unpub. Ph.D. thesis, Univ. de Barcelona, 2008; Khadivi et al. 2010) and in the High Zagros, where these growth deposits may be as old as Oligocene-Miocene (e.g. Fakhari et al. 2008; Gavillot et al. 2010). Moreover, a few apatite cooling ages around 22 Ma place the onset of continental collision around the Oligocene-Miocene boundary (Homke et al. 2010), although earlier ages, as old as Late Eocene, have been suggested (e.g. Allen \& Armstrong, 2008; Horton et al. 2008).

The coupled balanced and restored crustal crosssections documented in this paper constitute the first quantified approximation of both the presentday crustal structure of the Zagros Mountains and the reconstructed Arabian margin before the onset of compression related to oceanic obduction and subsequent continental collision. These cross-sections constitute a starting point for further developments of both kinematic and dynamic models to better determine the evolution of this collision-related orogen 
during subsequent stages of compression since Late Cretaceous time.

\section{Conclusions}

Coupled deformed and restored area balanced crustal cross-sections across the NW Zagros orogen are constructed using a combination of geological and geophysical data. Surficial geological data constrain the shallow crustal structure and geophysical data constrain the Moho depth (Paul et al. 2010) and the boundary between the Arabian and Iranian colliding plates.

The balanced (or deformed) cross-section shows the thin-skinned cover rocks' structure, based on field data, and the inferred basement thick-skinned deformation, which are connected along the coverbasement interface. This interface corresponds to an efficient regional thrust detachment level along the Hormuz salt or equivalent in the Lurestan region that has been active recurrently. The deformation in the $10-12 \mathrm{~km}$ thick sedimentary cover of the Arabian margin is characterized by multidetachment folding with subordinate thrusting. Deformation of Arabian basement rocks is accomplished by large crustal thrusts that actually merge at depth above an inferred NEdipping low-angle basal thrust, which elevates the entire Pusht-e Kuh arc (Lurestan arc) and reaches the basement-cover interface below the Mountain Front Flexure.

The three new vertical profiles resulting from a recent P-wave tomographic model (Villaseñor, Spakman \& Engdahl, 2003) image the boundaries between the different plates involved in the multiple collisions that configured the present-day Arabian, Iranian and Caspian Sea domains. The Arabia-Iran boundary is interpreted as a $50^{\circ} \mathrm{NE}$-dipping surface marked by a sharp contrast in the velocity anomalies, which are high in the Arabian lithosphere and slow in the Iranian lithosphere.

The total area between the foreland pin line, the near top of the Sarvak Formation, the Arabian Moho and the Arabian NE boundary is $10800 \mathrm{~km}^{2}$ in the deformed cross-section. This well-constrained area is used to reconstruct the Arabian margin before compression, assuming crustal area preservation during shortening as well as local isostasy and pure shear deformation.

The Arabian margin has been reconstructed before the onset of the obduction processes back to the lower part of the Upper Cretaceous, near the top of the Sarvak Formation in Turonian time $(\sim 90 \mathrm{Ma})$. In the reconstructed Arabian margin, the total area of $10800 \mathrm{~km}^{2}$ is distributed in six palaeogeographic domains according to the Lurestan stratigraphy and palaeogeographic maps from the NIOC (domains 1 to 3) and to the recent work by Wrobel-Daveau et al. (2010) (domains 4 and 6). Each of these domains is characterized by different inferred palaeoelevations during the time of reconstruction. The Harsin basin with exposed upper mantle rocks is only accounted for length balancing (domain 5). The Neo-Tethys oceanic crust (domain 7) forms the NE boundary of the reconstruction and is not accounted for area balancing.

The reconstructed Arabian crust shows a progressive crustal thinning towards the NE from domains 1 to 5 , whereas the Bisotun block (domain 6) represents a thick continental crustal block between the exhumed upper mantle rocks of the Harsin basin (domain 5) and the oceanic crust of the Neo-Tethys (domain 7). The restored Arabian margin has a length of $385 \mathrm{~km}$, from the foreland pin line to the continental-oceanic boundary. Using the present-day configuration of the crust as reference, the reconstructed margin extended $\sim 149 \mathrm{~km}$ to the NE of the Arabian crust pin line and $\sim 169 \mathrm{~km}$ to the NE of the current trace of the Main Recent Fault.

Shortening calculated from the difference between present and restored cross-sections is $149 \mathrm{~km}$ for the Arabian crust crystalline basement and $\sim 180 \mathrm{~km}$ for the sedimentary cover. The $149 \mathrm{~km}$ value corresponds to the shortening accommodated by the Arabian continental crust in the footwall of the Kermanshah thrust while the $180 \mathrm{~km}$ includes both obduction and continental collision events from Late Cretaceous to Recent time. The line-length balancing technique is used to calculate shortening along the near top of the Sarvak Formation in the Simply Folded Belt, which accounts for only $21 \mathrm{~km}(11 \%)$ and is mostly related to the last stage of compression during Miocene and Pliocene time.

The sequence of deformation in the Zagros is older in the inner parts of the chain and progressively younger in the external Simply Folded Belt since Late Cretaceous to Pliocene time. The average shortening rate is $\sim 2.0$ $\mathrm{mm} \mathrm{yr}^{-1}$ for the last $90 \mathrm{Ma}$, although compression was not always active through time.

Acknowledgements. This study is a contribution of the Group of Dynamics of the Lithosphere (GDL) within the framework of a collaborative project with the Statoil Research Centre in Bergen (Norway). We also thank Statoil and NIOC for their full support during fieldwork in the Zagros. We thank the following projects for their additional support: DARIUS Programme and its sponsors, TopoMed CGL200803474-E/BTE, ESF-Eurocores 07-TOPOEUROPE-FP006, TopoAtlas (CGL2006-05493/BTE), ATIZA (CGL200909662-BTE) and Consolider-Ingenio 2010 Topo-Iberia (CSD2006-00041). We would like to thank the excellent reviews by Brian Horton, an anonymous reviewer and the guest editors of the special issue, which greatly improved the final manuscript.

\section{References}

Agard, P., Monié, P., Gerber, W., Omrani, J., Molinaro, M., Meyer, B., Labrousse, L., Vrielynck, B., Jolivet, L. \& YAMATO, P. 2006. Transient, synobduction exhumation of Zagros blueschists inferred from P-T, deformation, time, and kinematic constraints: implications for Neotethyan wedge dynamics. Journal of Geophysical Research 111, B11401, doi:10.1029/2005JB004103, 28 pp.

AGARD, P., OMrani, J., Jolivet, J. \& MOUTHEREAU, F. 2005. Convergence history across Zagros (Iran): constraints 
from collisional and earlier deformation. International Journal of Earth Sciences 94, 401-19.

Ahmadhadi, F., LACOMBE, O. \& DANIEL, J. M. 2007. Early reactivation of basement faults in Central Zagros (SW Iran): evidence from pre-folding fracture populations in Asmari Formation and lower Tertiary paleogeography. In Thrust Belts and Foreland Basins: from fold kinematics to hydrocarbon systems (eds O. Lacombe, J. Lavé, J. Vergés \& F. Roure), pp. 205-28. Springer-Verlag.

AlAVI, M. 1994. Tectonics of the Zagros orogenic belt of Iran: new data and interpretations. Tectonophysics 229, 211-38.

AlAVI, M. 2004. Regional stratigraphy of the Zagros fold-thrust belt of Iran and its proforeland evolution. American Journal of Science 304, 1-20.

AlaVI, M. 2007. Structures of the Zagros fold-thrust belt in Iran. American Journal of Science 307, 1064-95.

Allen, M. B. \& ARMStrong, H. A. 2008. ArabiaEurasia collision and the forcing of mid-Cenozoic global cooling. Palaeogeography, Palaeoclimatology, Palaeoecology 265, 52-8.

ARTEMIEVA, I. M. 2006. Global $1^{\circ} \times 1^{\circ}$ thermal model TC1 for the continental lithosphere: implications for lithosphere secular variation. Tectonophysics 416, 245 77.

Authemayou, C., Bellier, O., Chardon, D., Malekzade, Z. \& ABASSI, M. 2005. Role of the Kazerun fault system in active deformation of the Zagros fold-and-thrust belt (Iran). Comptes Rendus Geoscience 337, 539-45.

Baharifar, A., Moinevaziri, H., Bellon, H. \& Pique, A. 2004. The crystalline complexes of Hamadan (SanandajSirjan zone, western Iran): metasedimentary Mesozoic sequences affected by Late Cretaceous tectonometamorphic and plutonic events. Comptes Rendus Geoscience 336, 1446-52.

BAHROUDI, A. \& TALBOT, C. J. 2003. The configuration of the basement beneath the Zagros Basin. Journal of Petroleum Geology 26, 257-82.

BARRIER, E. \& VRIELYNCK, B. (Contributors: BERGERAT, F., Brunet, M.-F., Mosar, J., Poisson, A. \& Sosson, M.). 2008. Palaeotectonic maps of the Middle East: TectonoSedimentary-Palinspastic maps from Late Norian to Pliocene. Atlas of 14 maps at 1/18,500,000. Paris, France: CGMW.

BERBERIAN, M. 1995. Master "blind" thrust faults hidden under the Zagros folds: active basement tectonics and surface morphotectonics. Tectonophysics 241, 193-224.

BERBERIAN, F. \& BERBERIAN, M. 1981. Tectono-plutonic episodes in Iran. In Zagros-Hindu Kush-Himalaya Geodynamic Evolution, vol. 3 (eds H. K. Gupta \& F. M. Delany), pp. 5-32. Washington, D.C.: American Geophysical Union.

BERBERIAN, M. \& KING, G. C. P. 1981. Towards a paleogeography and tectonic evolution of Iran. Canadian Journal of Earth Sciences 18, 210-65.

Berberian, F., Muir, I. D., PANKHURSt, R. J. \& BERBERIAN, M. 1982. Late Cretaceous and early Miocene Andeantype plutonic activity in northern Makran and Central Iran. Journal of the Geological Society, London 139, 605-14.

Bernard, D., Caillat, C., Dehlavi, P., Martel-Jentin, B. \& VIVIER, G. 1979. Premières données géochronométriques sur les roches intrusives de la région de Saveh (Iran). In 7ème Reunion Annuelle des Sciences de la Terre, Lyon, pp. 1-48. Société Géologique de France.

Berthier, F., Billiault, J.-P., Halbronn, B. \& Maurizot, P. 1974. Etude stratigraphique pétrologique et structural de la région de Khorramabad. Published Ph.D. thesis, Grenoble Université Joseph Fourier, 281 pp.

BijwaARD, H., SpaKman, W. \& ENGDAhL, E. R. 1998. Closing the gap between regional and global travel time tomography. Journal of Geophysical Research 103, B12, doi:10.1029/98JB02467.

Bina, M. M., Bucur, I., Prevot, M., Meyerfeld, Y., Daly, L., CAntagrel, J. M. \& Mergoil, J. 1986. Palaeomagnetism, petrology and geochronology of tertiary magmatic and sedimentary units from Iran. Tectonophysics 121, 303-29.

Blanc, E. J.-P., Allen, M. B., Inger, S. \& Hassani, H. 2003. Structural styles in the Zagros Simple Folded Zone, Iran. Journal of the Geological Society, London 160, 401-12.

BordenaVe, M. L. 2008. The origin of the Permo-Triassic gas accumulations in the Iranian Zagros Foldbelt and contiguous offshore areas: a review of the Paleozoic petroleum system. Journal of Petroleum Geology 31, $3-42$.

Bordenave, M. L. \& Hegre, J. A. 2005. The influence of tectonics on the entrapment of oil in the Dezful Embayment, Zagros Foldbelt, Iran. Journal of Petroleum Geology 28, 339-68.

BRAUD, J. 1970. Les formations du Zagros dans la région de Kermanshah (Iran) et leur rapport structuraux. Comptes Rendus de l'Académie des Sciences 271, 1241-4.

BRAUD, J. 1987. La suture du Zagros au niveau de Kermanshah (Kurdistan iranien): reconstitution paléogéographique, évolution géodynamique, magmatique et structurale. Published Ph.D. thesis, Université Paris-Sud, 430 pp.

CAllot, J.-P., JAhANI, S. \& LETOUZEY, J. 2007. The role of pre-existing diapirs in fold and thrust belt development. Thrust Belts and Foreland Basins: from fold kinematics to hydrocarbon systems (eds O. Lacombe, J. Lavé, J. Vergés \& F. Roure), pp. 309-26. Springer-Verlag.

Carruba, S., Perotti, C. R., Buonaguro, R., Calabró, R., CARPI, R. \& NAINI, M. 2006. Structural pattern of the Zagros fold-and-thrust belt in the Dezful Embayment (SW Iran). In Styles of Continental Contraction (eds S. Mazzoli \& R. W. H. Butler), pp. 11-32. Geological Society of America, Special Paper, no. 414.

Casciello, E., Vergés, J., Saura, E., Casini, G., FERNÁNDEZ, N., BlanC, E. J.-P., HoMKe, S. \& HunT, D. 2009. Fold patterns and multilayer rheology of the Lurestan Province, Zagros Simply Folded Belt (Iran). Journal of the Geological Society, London 166, 947-59.

Christensen, N. I., \& MoONEY, W. D. 1995. Seismic velocity structure and composition of the continental crust: a global view. Journal of Geophysical Research 100, B6, 9761-88.

Colman-SADD, S. P. 1978. Fold development in Zagros simply folded belt, southwest Iran. American Association of Petroleum Geologists Bulletin 62, 984-1003.

Dehghani, G. A. \& MAKRIS, J. 1984. The gravity field and crustal structure of Iran. Neus Jahrbuch für Geologie und Paläontologie Abhandlungen 168, 215-29.

EDGELL, H. S. 1996. Salt tectonism in the Persian Gulf basin. In Salt Tectonics (eds G. I. Alsop, D. J. Blundell. \& I. Davison), pp. 129-51. Geological Society London, Special Publication no. 100.

Emami, H., Vergés, J., Nalpas, T., Gillespie, P., Sharp, I., Karpuz, R., Blanc, E. J.-P. \& GoOdARZI, M. G. H. 2010. Structure of the Mountain Front Flexure along the Anaran anticline in the Pusht-e Kuh Arc (NW Zagros, Iran): insights from sand box models. 
In Tectonic and Stratigraphic Evolution of Zagros and Makran during the Mesozoic-Cenozoic (eds P. Leturmy \& C. Robin), pp.155-78. Geological Society of London Special Publication no. 330.

EngdAhl, E. R., JACKSON, J. A., Myers, S. C., Bergman, E. A. \& PRIESTLEY, K. 2006. Relocation and assessment of seismicity in the Iran region. Geophysical Journal International 167, 761-78.

FAKHARI, M. D., AXEN, G. J., HoRTON, B. K., HASSANZADEH, J. \& AMINI, A. 2008. Revised age of proximal deposits in the Zagros foreland basin and implications for Cenozoic evolution of the High Zagros. Tectonophysics 451, 17085.

FALCON, N. L. 1961. Major earth-flexuring in the Zagros Mountains of south-west Iran. Quarterly Journal of the Geological Society of London 117, 367-76.

FALCON, N. L. 1967. The geology of the north-east margin of the Arabian basement shield. Advancement of Science 24, 31-42.

FARZIPOUR-SAein, A., YASSAGHI, A., Sherkati, S. \& KoyI, H. 2009. Basin evolution of the Lurestan region in the Zagros fold-and-thrust belt, Iran. Journal of Petroleum Geology 32, 5-20.

ForD, M. 2004. Depositional wedge tops: interaction between low basal friction external orogenic wedges and flexural foreland basins. Basin Research 16, 361-75

Gavillot, Y. G., AXen, G. J., Stockli, D. F., Horton, B. K. \& FAKHARI, M. 2010. Timing of thrust activity in the High Zagros fold-thrust belt, Iran, from (UTh)/He thermochronometry. Tectonics 29, TC4025, doi: 10.1029/2009TC002484, $25 \mathrm{pp}$.

GHASEMI, A. \& TALBOT, C. J. 2006. A new tectonic scenario for the Sanandaj-Sirjan Zone (Iran). Journal of Asian Earth Sciences 26, 683-93.

Gidon, M., Berthier, F., Billiautt, J.-P., Halbronn, B. \& MAURIZOT, P. 1974. Sur quelques caractères de la tectonique néocrétacée dans la région de Borudjerd (Zagros oriental, Iran).Comptes Rendus de l'Académie des Sciences 278(Série D), 577-80.

GolONKA, J. 2004. Plate tectonic evolution of the southern margin of Eurasia in the Mesozoic and Cenozoic. Tectonophysics 381, 235-73.

Hatzfeld, D., Authemayou, C., Van Der Beek, P., Bellier, O., LAVÉ, J., OVEISI, B., TATAR, M., TAVAKOLI, F., WALPERSDORF, A. \& YAMINI-FARD, F. 2010. The kinematics of the Zagros Mountains (Iran). In Tectonic and Stratigraphic Evolution of Zagros and Makran during the Mesozoic-Cenozoic (eds P. Leturmy \& C. Robin), pp. 19-42. Geological Society of London, Special Publication no. 330.

HATZFELD, D. \& MolnaR, P. 2010. Comparisons of the kinematics and deep structures of the Zagros and Himalaya and of the Iranian and Tibetan plateaus and geodynamic implications. Reviews of Geophysics 48, RG2005, doi:10.1029/2009RG000304, 48 pp.

Hessami, K., Koyi, H. A., Talbot, C. J., TABasi, H. \& Shabanian, E. 2001. Progressive unconformities within an evolving foreland fold-and-thrust belt, Zagros Mountains. Journal of the Geological Society, London 158, 969-81.

HEYDARI, E. 2008. Tectonics versus eustatic control on supersequences of the Zagros Mountains of Iran. Tectonophysics 451, 56-70.

Homke, S., Vergés, J., Garcés, M., EMAMI, H. \& KarpuZ, R. 2004. Magnetostratigraphy of Miocene-Pliocene Zagros foreland deposits in the front of the Push-e Kush Arc (Lurestan Province, Iran). Earth and Planetary Science Letters 225, 397-410.
Homke, S., Vergés, J., Serra-Kiel, J., Bernaola, G., Sharp, I., GARCÉS, M., MONTERO-VERdÚ, I., KARPUZ, R. \& GoodarzI, M. H. 2009. Late CretaceousPaleocene formation of the proto-Zagros foreland basin, Lurestan Province, SW Iran. Geological Society of America Bulletin 121, 963-78.

Homke, S., Vergés, J., VAn Der BeEK, P., Fernàndez, M., SAURA, E., BARBERO, L., BADICS, B. \& LABRIN, E. 2010. Insights in the exhumation history of the NW Zagros from bedrock and detrital apatite fission-track analysis: evidence for a long-lived orogeny. Basin Research 22, 659-80.

Horton, B. K., Hassanzadeh, J., Stockli, D. F., AXen, G. J., GILLIS, R. J., GUEST, B., AMINI, A., FAKHARI, M. D., Zamanzadeh, S. M. \& Grove, M. 2008. Detrital zircon provenance of Neoproterozoic to Cenozoic deposits in Iran: implications for chronostratigraphy and collisional tectonics. Tectonophysics 451, 97-122.

HusseINI, M. 1988. The Arabian Infracambrian extensional system. Tectonophysics 148, 93-103.

Jahani., S., Callot, J.-P., Frizon De Lamotte, D., Letouzey, J. \& LetURMY, P. 2007. The salt diapirs of the eastern Fars province (Zagros, Iran): a brief outline of their past and present. In Thrust Belts and Foreland Basins: from fold kinematics to hydrocarbon systems (eds O. Lacombe, J. Lavé, J. Vergés \& F. Roure), pp. 289-308. Springer-Verlag.

JAMES, G. A. \& WYND, J. G. 1965. Stratigraphic nomenclature of Iranian Oil Consortium Agreement Area. Bulletin of the American Association of Petroleum Geologists 49, 2182-245.

Khadivi, S., MouthereaU, F., Larrasoaña, J. C., Vergés, J., LaCOMBe, O., Khademi, E., Beamud, E., MelinteDOBRINESCU, M. \& SUC, J.-P. 2010. Magnetochronology of synorogenic Miocene foreland sediments in the Fars arc of the Zagros Folded Belt (SE Iran). Basin Research 22, 918-32.

Koop, W. J. \& STONELEY, R. 1982. Subsidence history of the Middle East Zagros basin, Permian to Recent. Philosophical Transactions of Royal Society London 305, 149-68.

LaChenbruch, A. H. \& Morgan, P. 1990. Continental extension, magmatism and elevation; formal relations and rules of thumb. Tectonophysics 174, 39-62.

LETERRIER, J. 1985. Mineralogical, geochemical and isotopic evolution of two Miocene mafic intrusions from the Zagros (Iran). Lithos 18, 311-29.

Leturmy, P., Molinaro, M. \& Frizon De Lamotte, D. 2010. Structure, timing and morphological signature of hidden reverse basement faults in the Fars Arc of the Zagros (Iran). In Tectonic and Stratigraphic Evolution of Zagros and Makran during the MesozoicCenozoic (eds P. Leturmy \& C. Robin), pp. 12138. Geological Society of London, Special Publication no. 330 .

Maggi, A., Jackson, J. A., Priestley, K. \& BaKer, C. 2000. A re-assessment of focal depth distributions in southern Iran, the Tien Shan and northern India: do earthquakes really occur in the continental mantle? Geophysical Journal International 143, 62961.

Martel-Jentin, B., Caillat, C., Dehlavi, P. \& Vivier, G. 1979. Géochimie du volcanisme et du plutonisme paléogènes de la région de Saveh (Iran). Origine des tendances alcalines et calco-alcalines du Paléogène de la zone de l'Iran Central. In 7ème Reunion Annuelle des Sciences de la Terre, Lyon, pp. 1-314. Société Géologique de France. 
MCQUARRIE, N. 2004. Crustal scale geometry of the Zagros fold-thrust belt, Iran. Journal of Structural Geology 26, 519-35.

McQuarrie, N., Stock, J. M., Verdel, C. \& Wernicke, B. P. 2003. Cenozoic evolution of Neotethys and implications for the causes of plate motions. Geophysical Research Letters 30, 2036, doi:10.1029/2003GL017992, $4 \mathrm{pp}$.

Mohajele, M., Fergusson, C. L. \& Sahandi, M. R. 2003. Cretaceous-Tertiary convergence and continental collision, Sanandaj-Sirjan Zone, western Iran. Journal of Asian Earth Sciences 21, 397-412.

Molinaro, M., Leturmy, P., Guezou, J.-C., Frizon De LAMOTTE, D. \& Eshraghi, S. A. 2005. The structure and kinematics of the south-eastern Zagros fold thrust belt; Iran: from thin-skinned to thick-skinned tectonics. Tectonics 24, TC3007, doi:10.1029/2004TC001633, $19 \mathrm{pp}$.

Molinaro, M., Zeyen, H. \& LAURencin, X. 2005. Lithospheric structure beneath the south-eastern Zagros mountains, Iran: recent slab break off? Terra Nova 17, $1-6$.

MotieI, H. 1994. Stratigraphy of Zagros. A Publication of the Geological Survey of Iran (in Farsi), 536 pp.

Motiei, H. 1995. Petroleum Geology of Zagros. A Publication of the Geological Survey of Iran (in Farsi), $589 \mathrm{pp}$

Mouthereau, F., Lacombe, O. \& Meyer, B. 2006. The Zagros folded belt (Fars, Iran): constraints from topography and critical wedge modelling. Geophysical Journal International 165, 336-56.

Mouthereau, F., Tensi, J. Bellahsen, N., Lacombe, O., DE Boisgrollier, T. \& Kargar, S. 2007. Tertiary sequence of deformation in a thin-skinned/thick-skinned collision belt: The Zagros Folded Belt (Fars, Iran). Tectonics 26, TC5006, doi:10.1029/2007TC002098, $28 \mathrm{pp}$.

Nemati, M. \& Yassaghi, A. 2010. Structural characteristics of the transitional zone from internal to external parts of the Zagros orogen, Iran. Journal of Asian Earth Sciences 39, 161-72.

Nilforoushan, F., Masson, F., Vernant, P., Vigny, C., MARTINOD, J., ABBASSI, M., NANKALI, H., HATZFELD, D., Bayer, R., Tavakoli, F., Ashtiani, A., DoerFlinger, E., Daignières, M., Collard, P. \& ChÉRY, J. 2003. GPS network monitors the Arabia-Eurasia collision deformation in Iran. Journal of Geodesy 77, 411-22.

Oveisi, B., LaVÉ, J. \& VAN DeR BeEK, P. 2007. Rates and processes of active folding evidenced by Pleistocene terraces at the central Zagros front (Iran). In Thrust Belts and Foreland Basins: from fold kinematics to hydrocarbon systems (eds. O. Lacombe, J. Lavé, J. Vergés \& F. Roure), pp. 267-88. Springer-Verlag.

Paul, A., Hatzfeld, D., KaViani, A., TAtar, M. \& PequegNAT, C. 2010. Seismic imaging of the lithospheric structure of the Zagros mountain belt (Iran). In Tectonic and Stratigraphic Evolution of Zagros and Makran during the Mesozoic-Cenozoic (eds P. Leturmy \& C. Robin), pp. 5-18. Geological Society of London, Special Publication no. 330.

Paul, A., Kaviani, A., Hatzfeld, D., Vergne, J. \& MOKHTARI, M. 2006. Seismological evidence for crustal-scale thrusting in the Zagros mountain belt (Iran). Geophysical Journal International 166, 227-37.

Piryaei, A., ReIJMER, J. J. G., VAN BUChEM, F. S. P. \& YAZDIMOGHADAM, M. 2010. The influence of Late Cretaceous tectonic processes on sedimentation patterns along the northeastern Arabian plate margin (Fars Province, SW Iran). In Tectonic and Stratigraphic Evolution of Zagros and Makran during the Mesozoic-Cenozoic (eds P. Leturmy \& C. Robin), pp. 211-51. Geological Society of London, Special Publication no. 330.

PoudJom-DJomani, Y. H., O'REILLY, S. Y., GrifFN, W. L. $\&$ Morgan, P. 2001. The density structure of subcontinental lithosphere through time. Earth and Planetary Science Letters 184, 605-21.

Ravaut, P., Bayer, R., Hassani, R., Rousset, D. \& AL YAHYA'EY, A. 1997. Structure and evolution of the northern Oman margin: gravity and seismic constraints over the Zagros-Makran-Oman collision zone. Tectonophysics 279, 253-80.

Replumaz, A., Negredo, A. M., Villaseñor, A. \& GUILLOT, S. 2010. Indian continental subduction and slab break-off during Tertiary collision. Terra Nova 22, 290-6.

Ricou, L. E., BRAUD, J. \& BRUNN, J. H. 1977. Le Zagros. Société Géologique de France, Mémoire Hors Série $\mathbf{8}$, $33-52$.

RudKIEWICZ, J. L., SHERKATI, S. \& LetouZEy, J. 2007. Evolution of maturity in northern Fars and Izeh zone (Iranian Zagros) and link with hydrocarbon prospectivity. In Thrust Belts and Foreland Basins: from fold kinematics to hydrocarbon systems (eds. O. Lacombe, J. Lavé, J. Vergés \& F. Roure), pp. 229-46. Springer-Verlag.

SAura, E., Vergés, J., HOMKe, S., Blanc, E. J.-P., SERraKiel, J., Bernaola, G., Casciello, E., Fernández, N., Romaire, I., CASINI, G., EMBry, J.-C., SharP, I. R. \& HUNT, D. W. 2011. Basin architecture and growth folding of the NW Zagros early foreland basin during the Late Cretaceous and early Tertiary. Journal of the Geological Society, London 168, 235-50.

Sella, G. F., DiXON, T. H. \& MAO, A. 2002. REVEL: A model for Recent plate velocities from space geodesy. Journal of Geophysical Research 107, 2081, doi:10.1029/2000JB000033, $30 \mathrm{pp}$.

SENGÖR, A. M. C. 1990. A new model for the late Palaeozoic-Mesozoic tectonic evolution of Iran and implications for Oman. In The Geology and Tectonics of the Oman Region (eds A. H. F. Robertson, M. P. Searle, \& A. C. Ries), pp. 797-831. Geological Society of London, Special Publication no. 49.

SEPEHR, M. \& COSGROVE, J. W. 2004. Structural framework of the Zagros Fold-Thrust Belt, Iran. Marine and Petroleum Geology 21, 829-43.

SePeHr, M. \& Cosgrove, J. W. 2005. Role of the Kazerun Fault Zone in the formation and deformation of the Zagros Fold-Thrust Belt, Iran. Tectonics 24, TC5005, 10.1029/2004TC001725, 13 pp.

Sepehr, M., Cosgrove, J. W. \& Moieni, M. 2006. The impact of cover rock rheology on the style of folding in the Zagros fold-thrust belt. Tectonophysics 427, 265-81.

SetUdEHNiA, A. 1978. The Mesozoic sequence in southwest Iran and adjacent areas. Journal of Petroleum Geology 1, 3-42.

Sharland, P. R., Archer, R. \& CASey, D. M., DaVies, R. B., Hall, S. H., Heward, A. P. Horbury, A. D. \& Simmons, M. D. 2001. Arabian plate sequence stratigraphy. GeoArabia Special Publication 2. Bahrain: Gulf PetroLink. pp. 261-78.

Sharp, I., Gillespie, A., Morsalnezhad, D., TABerner, C., Karpuz, R., Vergés, J., HorburY, A., PICKARD, N., GARland, J. \& HUNT, D. 2010. Stratigraphic architecture and fracture-controlled dolomitization of 
the Cretaceous Khami and Bangestan groups: an outcrop case study, Zagros Mountains, Iran. In Mesozoic and Cenozoic Carbonate Systems of the Mediterranean and the Middle East: Stratigraphic and Diagenetic Reference Models (eds F. van Buchem, K. Gerdes \& M. Esteban), pp. 343-96. Geological Society of London, Special Publication no. 329.

SHeRKATI, S. \& LetOUZEY, J. 2004. Variation of structural style and basin evolution in the central Zagros (Izeh zone and Dezful Embayment), Iran. Marine and Petroleum Geology 21, 535-54.

Sherkati, S., Letouzey, J. \& Frizon De LAmotte, D. 2006. Central Zagros fold-thrust belt (Iran): new insights from seismic data, field observation, and sandbox modeling. Tectonics 25, TC4007, doi:10.1029/2004TC001766, 27 pp.

SNydER, D. B. \& BARAZANGI, M. 1986. Deep crustal structure and flexure of the Arabian plate beneath the Zagros collisional mountain belt as inferred from gravity observations. Tectonics 5: 361-73.

Stampfli, G. M. \& Borel, G. D. 2002 A plate tectonic model for the Paleozoic and Mesozoic constrained by dynamic plate boundaries and restored synthetic oceanic isochrons. Earth and Planetary Science Letters 196, 17-33.

STÖKLIN, J. 1968. Structural history and tectonics of Iran: a review. American Association of Petroleum Geologists Bulletin 52, 1229-58.

StONELEY, R. 1990. The Arabian continental margin in Iran during the Late Cretaceous. In The Geology and Tectonics of the Oman Region (eds A. H. F. Robertson, M. P. Searle, \& A. C. Ries), pp. 787-795. Geological Society of London, Special Publication no. 49.

Szabo, F., \& KheradPIR, A. 1978. Permian and Triassic stratigraphy, Zagros basin, southwest Iran. Journal of Petroleum Geology 1, 57-82.

TALBOT, C. J. \& ALAVI, M. 1996. The past of a future syntaxis across the Zagros. In Salt Tectonics (eds G. I. Alsop, D. J. Blundell \& I. Davison), pp. 89-109. Geological Society of London, Special Publication no. 100.

TALEBIAN, M. \& JACKSON, J. 2002. Offset on the Main Recent Fault of NW Iran and implications for the late Cenozoic tectonics of the Arabia-Eurasia collision zone. Geophysical Journal International 150, 422-39.
TAlEBIAN, M. \& JACKSON, J. 2004. A reappraisal of earthquake focal mechanisms and active shortening in the Zagros mountains of Iran. Geophysical Journal International 156, 506-26.

TATAR, M., HATZFELD, D. \& GHAFORI-Ashtiany, M. 2004. Tectonics of the Central Zagros (Iran) deduced from microearthquake seismicity. Geophysical Journal International 156, 255-66.

TATAR, M., HATZFEld, D., MARTINOD, J., WALPERSDORF, A., GHAFori-Ashtiany, M. \& CHÉRY, J. 2002. The present-day deformation of the central Zagros from GPS measurements. Geophysical Research Letters 29, 10 13.

Turcotte, D. L. \& Schubert, G. 2002. Geodynamics, 2nd ed. Cambridge, UK: University Press, 456 pp.

VAlizadeh, M. V. \& CANTAgRel, J. M. 1975. K-Ar and $\mathrm{Rb}-\mathrm{Sr}$ radiometric data on micas from MtAlvand Granitic Complex near Hamadan (Western Iran). Comptes Rendus de l'Academie des Sciences 281, 1083-6.

Vergés, J., GoOdARZI, M. H., EMAMI, H., KARPUZ, R., Efstatiou, J. \& Gillespie, P. 2011. Multiple detachment folding in Pusht-e Kuh Arc, Zagros. Role of mechanical stratigraphy. In Thrust Fault Related Folding (eds K. McClay, J. Shaw \& J. Suppe), pp.1-26. American Association of Petroleum Geologists Memoir 94.

Vernant, P., Nilforoushan, F., HatzFeld, M., ABbassi, M. R., Vigny, C., Masson, F., Nankali, H., MartinOD, J., AShtiani, A., BAYER, R., TAVAKOLI, F. \& CHÉRY, J. 2004. Present-day crustal deformation and plate kinematics in the Middle East constrained by GPS measurements in Iran and northern Oman. Geophysical Journal International 157, 381-98.

Villaseñor, A., SPAKMAN, W. \& ENGDAhl, E. R. 2003. Influence of regional travel times in global tomographic models. Nice: EGS-AGU-EUG Joint Assembly.

Wrobel-Daveau, J.-C., Ringenbach, J.-C., TaVakoli, S., Ruiz, G. M. H., Masse, P., \& Frizon De Lamotte, D. 2010. Evidence for mantle exhumation along the Arabian margin in the Zagros (Kermanshah area, Iran). Arabian Journal of Geosciences 3, 499-513.

ZIEGLER, M. A. 2001. Late Permian to Holocene paleofacies evolution of the Arabian Plate and its hydrocarbon occurrences. GeoArabia 6, 445-504. 